\title{
Simulating ectomycorrhiza in boreal forests: implementing ectomycorrhizal fungi model MYCOFON in CoupModel (v5)
}

\author{
Hongxing He ${ }^{1}$, Astrid Meyer ${ }^{1, a}$, Per-Erik Jansson ${ }^{2}$, Magnus Svensson $^{2}$, Tobias Rütting ${ }^{1}$, and Leif Klemedtsson ${ }^{1}$ \\ ${ }^{1}$ Department of Earth Sciences, University of Gothenburg, P.O. Box 460, Gothenburg 40530, Sweden \\ ${ }^{2}$ Department of Sustainable Development, Environmental Science and Engineering, Royal Institute of Technology (KTH), \\ Teknikringen 10B, SE-100 44 Stockholm, Sweden \\ ${ }^{a}$ now at: Institute of Groundwater Ecology, Helmholtz Zentrum München, Ingolstädter Landstraße 1, \\ Neuherberg 85764, Germany
}

Correspondence: Hongxing He (hongxing.he@gu.se)

Received: 12 July 2017 - Discussion started: 22 August 2017

Revised: 6 January 2018 - Accepted: 15 January 2018 - Published: 28 February 2018

\begin{abstract}
The symbiosis between plants and Ectomycorrhizal fungi (ECM) is shown to considerably influence the carbon (C) and nitrogen (N) fluxes between the soil, rhizosphere, and plants in boreal forest ecosystems. However, ECM are either neglected or presented as an implicit, undynamic term in most ecosystem models, which can potentially reduce the predictive power of models.

In order to investigate the necessity of an explicit consideration of ECM in ecosystem models, we implement the previously developed MYCOFON model into a detailed process-based, soil-plant-atmosphere model, CoupMYCOFON, which explicitly describes the $\mathrm{C}$ and $\mathrm{N}$ fluxes between ECM and roots. This new Coup-MYCOFON model approach (ECM explicit) is compared with two simpler model approaches: one containing ECM implicitly as a dynamic uptake of organic $\mathrm{N}$ considering the plant roots to represent the ECM (ECM implicit), and the other a static $\mathrm{N}$ approach in which plant growth is limited to a fixed $\mathrm{N}$ level (nonlim). Parameter uncertainties are quantified using Bayesian calibration in which the model outputs are constrained to current forest growth and soil $\mathrm{C} / \mathrm{N}$ ratio for four forest sites along a climate and $\mathrm{N}$ deposition gradient in Sweden and simulated over a 100-year period.

The "nonlim" approach could not describe the soil C / N ratio due to large overestimation of soil $\mathrm{N}$ sequestration but simulate the forest growth reasonably well. The ECM "implicit" and "explicit" approaches both describe the soil C / N ratio well but slightly underestimate the forest growth. The implicit approach simulated lower litter production and soil
\end{abstract}

respiration than the explicit approach. The ECM explicit Coup-MYCOFON model provides a more detailed description of internal ecosystem fluxes and feedbacks of $\mathrm{C}$ and $\mathrm{N}$ between plants, soil, and ECM. Our modeling highlights the need to incorporate ECM and organic $\mathrm{N}$ uptake into ecosystem models, and the nonlim approach is not recommended for future long-term soil $\mathrm{C}$ and $\mathrm{N}$ predictions. We also provide a key set of posterior fungal parameters that can be further investigated and evaluated in future ECM studies.

\section{Introduction}

Boreal forests cover large areas on the Earth's surface and are generally considered substantial carbon (C) sinks (Dixon et al., 1994; Pan et al., 2011). The sink strength is determined through the balance between major $\mathrm{C}$ uptake and release processes, i.e., plant photosynthesis and both autotrophic and heterotrophic respiration, and is largely controlled by nitrogen (N) availability (Magnani et al., 2007; Högberg et al., 2017). Numerous studies have shown that soil $\mathrm{N}$ availability is the main driver for plant and microbial dynamics (Vitousek and Howarth, 1991; Klemedtsson et al., 2005; Lindroth et al., 2008; Luo et al., 2012; Mäkiranta et al., 2007; Martikainen et al., 1995). Thus, a proper description of $\mathrm{N}$ dynamics in ecosystem models is prerequisite for precisely simulating plant-soil $\mathrm{C}$ dynamics and greenhouse gas balance (Maljanen et al., 2010; Schulze et al., 2009; Huang et al., 2011). Ecosystem models, however, vary considerably in 
Table 1. Main characteristics of previous ecosystem models that include ECM.

\begin{tabular}{|c|c|c|c|c|c|c|c|}
\hline Models & Time step & $\begin{array}{l}\text { Elements } \\
\text { included }\end{array}$ & $\begin{array}{l}\text { Differentiation } \\
\text { in mycelia } \\
\text { and mantle }\end{array}$ & $\begin{array}{l}\text { Organic } \\
\text { matter } \\
\text { decomposition }\end{array}$ & $\mathrm{C}$ allocation & Plant $\mathrm{N}$ uptake & $\begin{array}{l}\text { Is } \mathrm{ECM} \\
\text { sensitive to } \\
\text { soil } \mathrm{N} \text { ? }\end{array}$ \\
\hline $\begin{array}{l}\text { ANAFORE, } \\
\text { Deckmyn et } \\
\text { al. (2011) }\end{array}$ & Hourly & $\mathrm{C}, \mathrm{N}$ & No & Yes & $\begin{array}{l}\text { Fraction of } \mathrm{C} \text { allocated } \\
\text { to roots, regulated by } \\
\text { water and } \mathrm{N}\end{array}$ & $\begin{array}{l}\text { Function of the } \\
\text { available mineral and } \\
\text { organic N pools }\end{array}$ & No \\
\hline $\begin{array}{l}\text { MoBiLE and } \\
\text { MYCOFON, } \\
\text { Meyer et } \\
\text { al. }(2010,2012)\end{array}$ & Daily & $\mathrm{C}, \mathrm{N}$ & Yes & No & $\begin{array}{l}\text { A certain ratio between } \\
\text { root and ECM biomass } \\
\text { exists to reach the opti- } \\
\text { mum degree of mycor- } \\
\text { rhization, regulated by } \\
\text { soil } \mathrm{N} \text { and temperature }\end{array}$ & $\begin{array}{l}\text { Separated root and } \\
\text { mycelia mineral } \mathrm{N} \\
\text { uptake and regulated } \\
\text { by plant and ECM N } \\
\text { demand }\end{array}$ & Yes \\
\hline $\begin{array}{l}\text { MySCaN, } \\
\text { Orwin et } \\
\text { al. (2011) }\end{array}$ & Daily & $\mathrm{C}, \mathrm{N}, \mathrm{P}$ & No & Yes & $\begin{array}{l}\text { Constant fraction of } \\
\text { plant } C \text { assimilates, } \\
\text { modified by nutrients }\end{array}$ & $\begin{array}{l}\text { Driven by C-to-nutrient } \\
\text { ratios in pools }\end{array}$ & No \\
\hline $\begin{array}{l}\text { Moore et } \\
\text { al. (2015) } \\
\text { model }\end{array}$ & Monthly & $\mathrm{C}$ & No & Yes & $\begin{array}{l}\text { Constant fraction of } \\
\text { plant } \mathrm{C} \text { assimilates }\end{array}$ & & No \\
\hline $\begin{array}{l}\text { Baskaran et } \\
\text { al. }(2016) \\
\text { model }\end{array}$ & Annual & $\mathrm{C}, \mathrm{N}$ & No & No & $\begin{array}{l}\text { Constant fraction of } \\
\text { plant } \mathrm{C} \text { assimilates }\end{array}$ & $\begin{array}{l}\text { Root inorganic } \mathrm{N} \\
\text { uptake by Michaelis- } \\
\text { Menten function and } \\
\text { ECM N uptake by } \\
\text { ECM C-to-N ratio }\end{array}$ & No \\
\hline $\begin{array}{l}\text { Coup- } \\
\text { MYCOFON } \\
\text { (this study) }\end{array}$ & Daily & $\mathrm{C}, \mathrm{N}$ & Yes & No & Similar to MoBiLE & $\begin{array}{l}\text { Similar to MoBiLE, but } \\
\text { allows organic } \mathrm{N} \\
\text { uptake for } \mathrm{ECM}\end{array}$ & Yes \\
\hline
\end{tabular}

their representation of $\mathrm{N}$ fluxes: from very simplified presentations (e.g., the LPJ-GUESS model: Sitch et al., 2003; Smith et al., 2011) to very complex approaches that aim to capture the whole N cycle (e.g., LandscapeDNDC: Haas et al., 2012; CoupModel: Jansson and Karlberg, 2011).

Ectomycorrhizal fungi (ECM) are common symbionts of trees in boreal forests. ECM are more efficient than roots in taking up different $\mathrm{N}$ sources from the soil (Plassard et al., 1991), and they store vast amounts of $\mathrm{N}$ in their tissues (Bååth and Söderström, 1979) and can cover a large fraction of their host plants' N demand (Leake, 2007; van der Heijden et al., 2008). Further, ECM are shown to respond sensitively to ecosystem $\mathrm{N}$ availability and are generally considered as adaptation measures to limited $\mathrm{N}$ conditions (Wallenda and Kottke, 1998; Read and Perez Moreno, 2003; Kjoller et al., 2012; Bahr et al., 2013; Choma et al., 2017). Previous research showed that ECM can receive between 1 and $25 \%$ of the plants' photosynthates and constitute as much as $70 \%$ of the total soil microbial biomass, thus having a major impact on soil C sequestration in boreal forests (Staddon et al., 2003; Clemmensen et al., 2013). Overall, the functions and abundance of ECM fungi constitute numerous pathways for $\mathrm{N}$ turnover in the ecosystem and considerably influence the magnitude and dynamics of $\mathrm{C}$ and $\mathrm{N}$ fluxes.

Nevertheless, ECM have rarely been considered in ecosystem models (for an overview about modeling ectomycor- rhizal traits, see Deckmyn et al., 2014). To our knowledge, only five ecosystem models have implemented ECM to various degrees: the ANAFORE model (Deckmyn et al., 2008), the MoBiLE environment (Meyer et al., 2012), the MySCaN model (Orwin et al., 2011), and more recently the Moore et al. (2015) and Baskaran et al. (2016) ECM models (Table 1). In the ANAFORE model, ECM are described as separate $\mathrm{C}$ and $\mathrm{N}$ pools. However, this model does not distinguish between mycorrhizal mycelia and mantle. The $\mathrm{C}$ allocated from the host tree to ECM is simulated as a zero-order function, further regulated by nutrient and water availability. ECM can also facilitate organic matter decomposition in the ANAFORE model. The MySCaN model uses a similar approach for ECM C uptake and dynamics but does not, to our knowledge, include the influence of water availability on ECM. In both models, ECM transfer of $\mathrm{N}$ to the host is regulated by the $\mathrm{C} / \mathrm{N}$ ratios of the plant and fungi. In the MoBiLE model, $\mathrm{C}$ allocation to ECM is more complex than that in the ANAFORE and MySCaN models, and the $\mathrm{N}$ allocation to the host by the ECM can feed back into their C gains. However, the $\mathrm{N}$ allocation to the host plant is described similarly to the other two models. In MoBiLE, mycorrhiza are further distinguished between mycelia and mantle, but can neither degrade organic matter nor take up organic $\mathrm{N}$ forms. Mycelia and mantle differ in their capacity to take up $\mathrm{N}$, and the mantle has a slower litter production rate than 


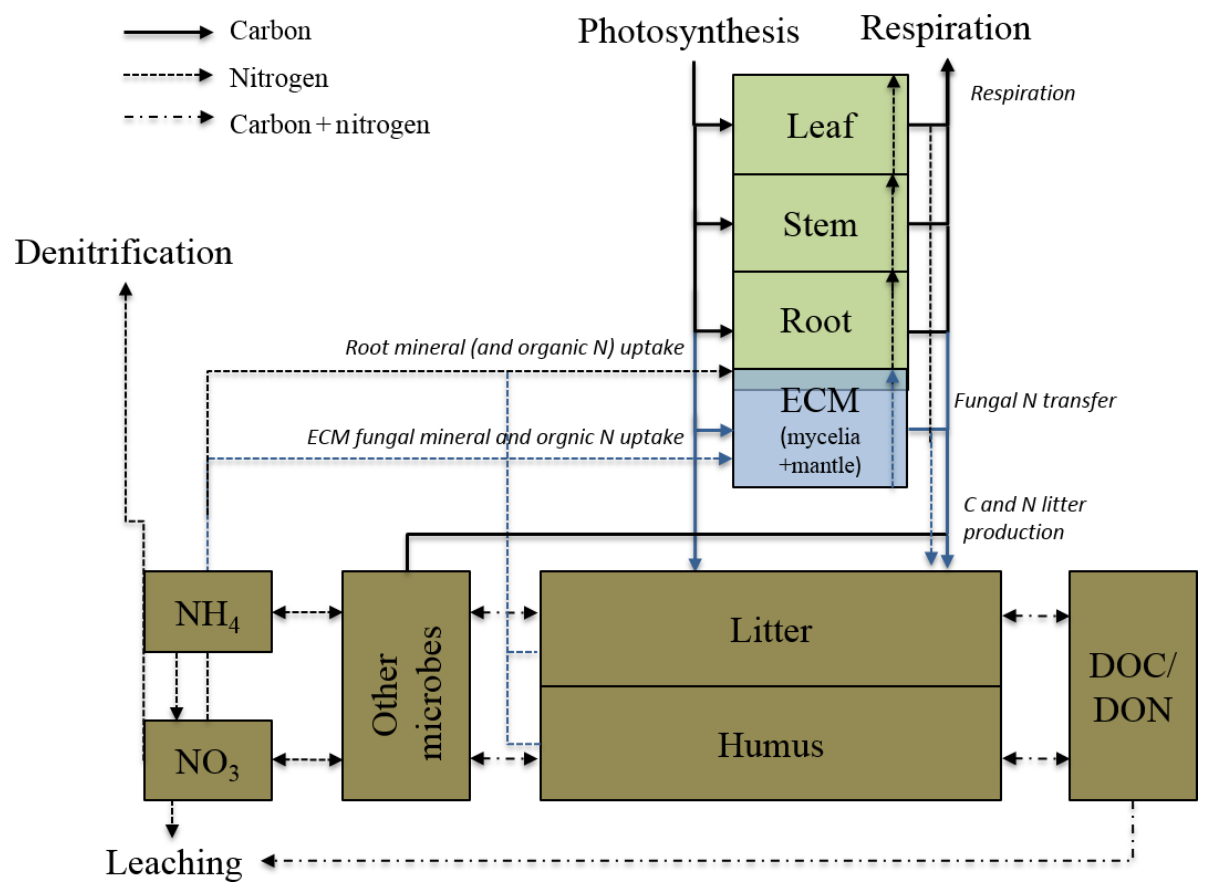

Figure 1. A simplified overview of $\mathrm{C}$ and $\mathrm{N}$ fluxes among plants, mycorrhiza fungi, and the soil in the Coup-MYCOFON model. Light blue indicates the newly implemented MYCOFON model.

that of mycelia. Both the Moore et al. (2015) and Baskaran et al. (2016) ECM models represent the ECM as a separate model pool and explicitly simulate ECM decomposition, but with much simpler process descriptions, and the interaction with environmental functions are neglected (Table 1).

The overall aim of this study is to improve understanding of ecosystem internal $\mathrm{C}$ and $\mathrm{N}$ flows related to symbiosis between ECM and a host tree in order to improve the model predictive power in assessment of $\mathrm{C}$ sequestration and climate change. This is carried out by presenting a new version of the CoupModel, coupled with an explicit description of ECM. Specifically, we implement the previously developed MYCOFON model (Meyer et al., 2010) into the wellestablished soil-plant-atmosphere model, CoupModel (Jansson, 2012). We choose the MYCOFON model because, first, it contains a very detailed description of ECM fungal $\mathrm{C}$ and $\mathrm{N}$ pools and all major $\mathrm{C}$ and $\mathrm{N}$ ECM exchange processes (i.e., litter production, respiration, $\mathrm{C}$ uptake, $\mathrm{N}$ uptake), and second, ECM can also additionally respond to the soil $\mathrm{N}$ availability (Table 1). Therefore, ECM growth and $\mathrm{N}$ uptake, both mineral and organic $\mathrm{N}$ forms, respond dynamically to environmental functions and plant $\mathrm{C}$ supply in the new CoupMYCOFON model (Fig. 1). This detailed "ECM explicit" modeling approach (hereafter called ECM explicit) is further compared with two simpler modeling approaches - the "ECM implicit" and "nonlim" approaches - which already exist in CoupModel. The ECM implicit approach does not represent the ECM as a separate pool but incorporates ECM into the roots implicitly. Plants are thus allowed to take up additional organic $\mathrm{N}$ sources from soil organic pools and do not respond to environmental functions. The ECM implicit approach has been used in a similar way by Kirschbaum and Paul (2002) and Svensson et al. (2008a). The nonlim approach assumes an "open" $\mathrm{N}$ cycle and plant growth is limited by a constant $\mathrm{N}$ availability to a static fixed level (e.g., in Franklin et al., 2014). These three ECM modeling approaches constitute most of the current ECM representations in ecosystem models and are tested by four forest sites situated along a climate and $\mathrm{N}$ fertility gradient across Sweden (Fig. 2). Bayesian calibration is used to quantify the uncertainty of model parameters and identify key parameter sets.

\section{Data and methodology}

\subsection{Model description}

The CoupModel ("Coupled heat and mass transfer model for soil-plant-atmosphere systems"; Jansson and Karlberg, 2011) is a one-dimensional process-oriented model, simulating all the major abiotic and biotic processes (mainly $\mathrm{C}$ and $\mathrm{N}$ ) in a terrestrial ecosystem. The basic structure is a depth profile of the soil for which water and heat flows are calculated based on defined soil properties. Plants can be distinguished between understory and overstory vegetation, which allows simulation of competition for light, water, and $\mathrm{N}$ between plants. The model is driven by climate data - precipitation, air temperature, relative humidity, wind speed, and global radiation - and can simulate ecosystem 


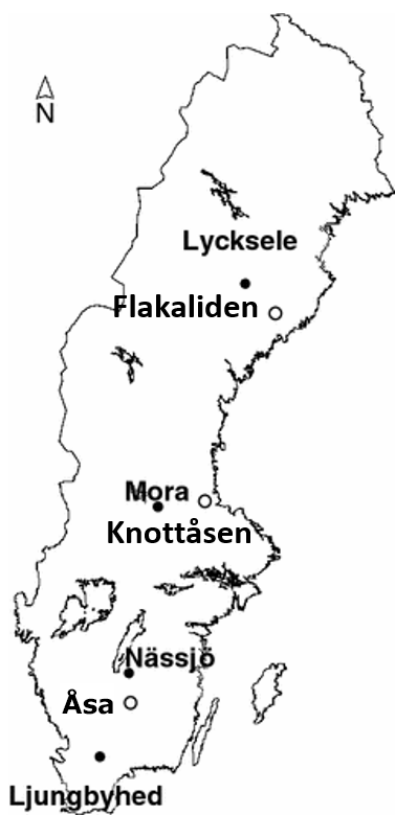

Figure 2. Location of the four study sites in Sweden modified from Svensson et al. (2008a). Filled cycles represent the four studied sites. Open circles are the measured sites reported in Lindroth et al. (2008) used for comparison.

dynamics in hourly, daily, and yearly resolutions. A general structural and technical overview of the CoupModel can be found in Jansson and Moon (2001) and Jansson and Karlberg (2011), and a recent overview of the model was also given by Jansson (2012). The model is freely available at www.coupmodel.com. The CoupModel (v5) is complemented with an ectomycorrhizal module (MYCOFON; Meyer et al., 2010), which allows the direct simulation of the $\mathrm{C}$ and $\mathrm{N}$ uptake processes of ECM. The MYCOFON (v1) model is described in detail by Meyer et al. (2010), and here only the key processes of plant and ECM fungal growth, $\mathrm{N}$ uptake, and litterfall and respiration are described.

\subsubsection{Plant growth in CoupModel}

An overview of model functions is given in the Appendix, Table A1. Plant growth is simulated according to a "radiation use efficiency approach" in which the rate of photosynthesis is assumed to be proportional to the global radiation absorbed by the canopy, but limited by temperature, water conditions, and $\mathrm{N}$ availability (Eq. 1, Table A1a). Assimilated $\mathrm{C}$ is allocated into five different plant $\mathrm{C}$ compartments: $\mathrm{C}_{\text {root }}, \mathrm{C}_{\text {leaf }}, \mathrm{C}_{\text {stem }}, \mathrm{C}_{\text {grain }}$, and $\mathrm{C}_{\text {mobile }}$. The same compartments also represent the corresponding $\mathrm{N}$ amounts. The "mobile" pool $\left(\mathrm{C}_{\text {mobile }}, \mathrm{N}_{\text {mobile }}\right)$ contains embedded reserves that are reallocated during certain time periods of the year, e.g., during leafing. Respiration is distinguished between maintenance and growth respiration, where a $Q_{10}$ function response is used (Eq. 2.1, 2.2; Table A1a). Plant litter is calculated as fractions of standing biomass (Eq. 3, Table A1a).

\subsubsection{ECM fungal $\mathrm{C}$ and $\mathrm{N}$ pools}

The ECM are closely linked to the trees' fine roots and consist of $\mathrm{C}$ and $\mathrm{N}$ pools. The $\mathrm{C}$ pool is distinguished between the mycelia, which are responsible for $\mathrm{N}$ uptake, and the fungal mantle, which covers the fine-root tips. The $\mathrm{C}$ pool is the difference between $\mathrm{C}$ gains from plant supply and $\mathrm{C}$ losses due to respiration and litter production (Eq. 8.1, Table A1b). Accordingly, the fungal $\mathrm{N}$ pool is the result of the difference between $\mathrm{N}$ gains by uptake, $\mathrm{N}$ losses by litter production, and $\mathrm{N}$ transfer to the plant (Eq. 8.2, Table A1b). ECM fungal C and $\mathrm{N}$ pools distinguish between mycelia and mantle, which is of importance when simulating $\mathrm{N}$ uptake (only the mycelia are able to take up N), and also when simulating litter production if the more complex approach is chosen (see Sect. 2.1.4). The ratio between mycelia and mantle is determined by the parameter $\mathrm{FRAC}_{\mathrm{MYC}}$, which defines the fraction of mycelia $\mathrm{C}$ in total ECM fungal $\mathrm{C}$. For all other $\mathrm{N}$ and $\mathrm{C}$ exchange processes (growth, respiration, and $\mathrm{N}$ transfer to plant), the separation between mycelia and mantle is disregarded.

\subsubsection{Growth of ectomycorrhizal fungi}

ECM growth is limited by a defined maximum, i.e., only a certain amount of tree host assimilates are directed to the ECM. This maximum ECM growth is determined by a potential $\mathrm{C}$ supply from the plant and limited by $\mathrm{N}$ availability (Eq. 5.1, Table A1b). The C supply is defined by a constant fraction of the root $\mathrm{C}$ gain and is leveled off by the function $f\left(c_{\text {fungiavail }}\right)$ as soon as a defined value of soil-available total $\mathrm{N}$ is exceeded, i.e., in the model the potential ECM growth declines with rising soil $\mathrm{N}$. This scaling function is based on observations from field and laboratory experiments, which showed that the ECM biomass of mycelia and mantle can be as much as $30-50 \%$ of fine-root biomass, and the majority of ECM decrease in abundance and functioning when the soil $\mathrm{N}$ levels are high (e.g., Wallander, 2005; Wallenda and Kottke, 1989; Högberg et al., 2010). The actual ECM growth is limited by the maximum growth and calculated by a predefined fraction of assimilated $\operatorname{root} \mathrm{C}$, assuming that the production of an optimum mycorrhization degree requires a certain amount of ECM biomass (Eq. 5.2, Table A1b: FRAC $\left.\mathrm{OPT}_{\mathrm{OP}} \times c_{\mathrm{frt}}\right)$. This is further dependent on the $\mathrm{N}$ supply from the ECM to the roots, $f\left(n_{\text {supply }}\right)$. The model thus follows the assumption that plants feed the ECM with $\mathrm{C}$ as long as their investment is outweighed by the benefits obtained (Nehls et al., 2008). A minimum C supply to prevent $\mathrm{ECM}$ fungi death during $\mathrm{C}$ shortage is guaranteed by the term during time periods when plant photosynthesis is limited and belowground C supply to root and ECM becomes zero (Eq. 5.3, Table A1b). 


\subsubsection{Respiration and litter production of ectomycorrhizal fungi}

Respiration is separated into two components (maintenance and growth) for both ECM and root respiration (see Eqs. 2 and 6, Table A1). Two approaches are available to simulate ECM fungal litter production that differ in complexity. The simple approach (Eq. 7.1, 7.2; Table A1) uses one common litter rate $L$ for both the fungal mantle and mycelia. Consequently, possible specific effects of the mantle and mycelia tissue on litter production are neglected. The alternative "detailed" approach (Eq. 7.3, 7.4; Table A1) has specific litter rates for ECM mantle and mycelia $\left(L_{\mathrm{M}}, L_{\mathrm{MYC}}\right)$. This setup is recommended when investigating different biomass ratios between mycelia and mantle and their effects on overall litter production. Irrespective of the approach used for litter production, ECM have the capability to retain a defined amount of $\mathrm{N}$ during senescence (Eq. 7.2, 7.5; Table Alb: nret fungi). In this study, the simple approach is applied.

\subsubsection{Plant mycorrhization degree, plant $\mathrm{N}$ uptake, and ECM fungal $\mathbf{N}$ transfer to plant}

According to field investigations, the mycorrhization degree can vary considerably between species. For spruce (Picea abies), typical mycorrhization degrees of over $90 \%$ have been reported (Fransson et al., 2010; Leuschner, 2004). The impact of the ECM mantle on fine-root nutrient uptake has been controversially discussed, but the majority of studies indicate that the root is isolated from the soil solution, i.e., the nutrient uptake is hampered so that the plant is highly dependent on ECM supplies (Taylor and Alexander, 2005). Therefore, the mycorrhization degree is of major importance when plant-ECM-soil $\mathrm{N}$ exchange and plant nutrition are of interest. In the explicit Coup-MYCOFON model, mycorrhization degree is calculated as the ratio between ECM C pool and the defined optimum ECM C pool, divided by the defined optimum mycorrhization degree (Eq. 9, Table A1b). It should be noted that the optimum mycorrhization degree needs to be defined with care as there is often a discrepancy between the applied root diameter in experimental studies and models: in experiments, mycorrhization degrees usually refer to fine roots $\leq 1 \mathrm{~mm}$, whereas models often consider fine roots as roots with a diameter of up to $2 \mathrm{~mm}$.

The mycorrhizal mantle has an impact on the mineral plant $\mathrm{N}$ uptake. This is because plant ammonium and nitrate uptake is largely driven by the plant $\mathrm{N}$ demand (Eq. 4.1, 4.2; Table A1) but also regulated by the $\mathrm{N}$ availability function (Eqs. 15, 16, 17; Table A1: $\left.f\left(n_{\text {avail }}\right), f\left(n_{\text {mhumavail }}\right)\right)$ based on the assumption that only a certain fraction of soil ammonium and nitrate is available for plant uptake. The ECM fungal mantle reduces this availability in such a way that reduction is highest at maximum biomass. In a balanced symbiosis, the fungus provides nutrients to the plant in exchange for the plant's C supply. In the Coup-MYCOFON model, the amount of ECM fungal $\mathrm{N}$ transferred to the plant is determined by either the plant $\mathrm{N}$ demand or, if the plant $\mathrm{N}$ demands exceed the ECM fungal capacity, the available fungal N (Eq. 10.1, 10.2; Table A1). This is the amount of "excess" $\mathrm{N}$ that is available after the ECM have fulfilled their defined minimum demand as calculated by the fungal $\mathrm{C} / \mathrm{N}$ ratio (Eq. 10.2, Table A1). This relation is again based on the assumption that the ECM fungi will only supply the plant with $\mathrm{N}$ as long as its own demand is fulfilled (Nehls et al., 2008).

\subsubsection{Ectomycorrhizal fungal $\mathrm{N}$ uptake}

In the Coup-MYCOFON model, ECM can take up both mineral and organic $\mathrm{N}$. For both $\mathrm{N}$ forms, the potential ECM uptake is first defined. This is determined by the size of ECM C pool, the fraction of ECM C that is capable of $\mathrm{N}$ uptake (the mycelia, $\mathrm{FRAC}_{\mathrm{MYC}}$ ), and an uptake rate $\left(\mathrm{NO}_{3_{\text {RATE }}}, \mathrm{NH}_{4_{\text {RATE }}}\right.$, NORG RATE $_{\text {(Eq. }} 11.1,11.3,11.4,11.6$; Table A1b). This function is based on the assumption that only the ECM fungal mycelia can take up $\mathrm{N}$. Values for

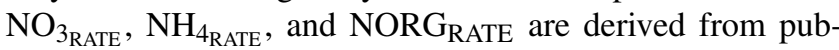
lished values but with wide ranges (Table 2). The actual $\mathrm{N}$ uptake is dependent on the available soil $\mathrm{N}$ as well as the ECM $\mathrm{N}$ demand (Eq. 11.2, Table A1). The $\mathrm{N}$ availability function $f\left(n_{\text {avfungi }}\right)$ determines the fraction of soil $\mathrm{N}$ that is available for ECM fungal uptake and is controlled by

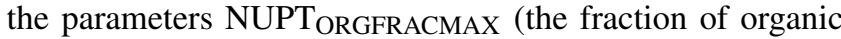

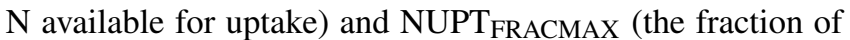
mineral $\mathrm{N}$ available for uptake). $\mathrm{N}$ availability for ECM corresponds to the plant-available $\mathrm{N}$ (Eq. 16, Table A1), but as ECM are more efficient in the uptake of nutrients, the availability is enhanced for both mineral and organic $\mathrm{N}$ (Eq. 17.1, 17.2, 17.3; Table A1). To prevent the ECM N demand being covered by only one $\mathrm{N}$ form, the parameters $r_{\mathrm{NO}_{3}}, r_{\mathrm{NH}_{4}}, r_{\mathrm{LIT}}$, and $r_{\mathrm{HUM}}$ are included, corresponding to the ratio of nitrate to ammonium in total available soil $\mathrm{N}$ (litter and humus). If the potential $\mathrm{N}$ uptake exceeds the available soil $\mathrm{N}$, the actual uptake corresponds to the available $\mathrm{N}$ (Eq. 11.2 and 11.5; Table A1b).

\subsection{Transect modeling approach}

\subsubsection{Three ECM modeling approaches}

Three modeling approaches of different complexity were applied in this study. The basic nonlim approach was conducted to test if plant $\mathrm{N}$ uptake can be described as proportional to the $\mathrm{C}$ demand of the plants of the respective sites. In this case, the plant $\mathrm{N}$ uptake is not regulated by the actual soil $\mathrm{N}$ availability, and $\mathrm{N}$ is used from a virtual source potentially exceeding the soil $\mathrm{N}$ availability, thus as an open $\mathrm{N}$ cycle. The ECM implicit approach simulates plant uptake of organic $\mathrm{N}$, which is assumed to be via ECM, i.e., ECM are considered implicitly as being responsible for $\mathrm{N}$ uptake but 
Table 2. Maximum and minimum parameter values prior to Bayesian calibration for the nonlim, implicit, and explicit model approaches. (a) Common parameters (all three approaches). (b) $\mathrm{Pa}$ rameters of the nonlim approach. (c) ECM fungal parameters of the explicit approach.

\begin{tabular}{|c|c|c|c|}
\hline Parameter & Unit & Min & Max \\
\hline \multicolumn{4}{|l|}{ (a) Humus decomposition } \\
\hline$K_{\mathrm{H}}$ & $\mathrm{d}^{-1}$ & 0.0001 & 0.001 \\
\hline \multicolumn{4}{|c|}{ Fraction of organic $\mathrm{N}$ available for uptake } \\
\hline NUPT $_{\text {ORGFRACMAX }}$ & - & 0.000001 & 0.0001 \\
\hline \multicolumn{4}{|c|}{ Fraction of root $\mathrm{C}$ allocation in mobile $\mathrm{C}$} \\
\hline$F_{\text {ROOT }}$ & - & 0.4 & 0.6 \\
\hline \multicolumn{4}{|c|}{$\mathrm{C} / \mathrm{N}$ ratio of decomposing microbes } \\
\hline $\mathrm{CN}_{\mathrm{MIC}}$ & - & 15 & 25 \\
\hline \multicolumn{4}{|l|}{ (b) Plant N supply } \\
\hline ConstantNSupply & - & 0.1 & 0.7 \\
\hline \multicolumn{4}{|l|}{ (c) ECM N uptake } \\
\hline $\begin{array}{l}\mathrm{NORG}_{\text {RATE }} \\
\mathrm{NH}_{4_{\text {RATE }}} \\
\mathrm{NO}_{3_{\text {RATE }}} \\
\end{array}$ & $\begin{array}{l}\operatorname{gNgdw}^{-1} d^{-1} \\
\operatorname{gNgdw}^{-1} d^{-1} \\
\operatorname{gNgdw}^{-1} d^{-1}\end{array}$ & $\begin{array}{l}0.000001^{\mathrm{a}} \\
0.000001^{\mathrm{a}} \\
0.000001^{\mathrm{a}}\end{array}$ & $\begin{array}{l}0.0001 \\
0.0001 \\
0.0001\end{array}$ \\
\hline \multicolumn{4}{|c|}{ ECM respiration coefficient } \\
\hline$K_{\mathrm{RM}}$ & $\mathrm{d}^{-1}$ & $0.0002^{\mathrm{b}}$ & 0.05 \\
\hline \multicolumn{4}{|l|}{ ECM litter rate } \\
\hline$L$ & $\mathrm{~d}^{-1}$ & $0.0008^{\mathrm{c}}$ & 0.01 \\
\hline \multicolumn{4}{|c|}{ Minimum ECM fungal $\mathrm{C} / \mathrm{N}$ ratio } \\
\hline $\mathrm{CN}_{\mathrm{FMIN}}$ & - & $5^{\mathrm{d}}$ & 10 \\
\hline \multicolumn{4}{|c|}{ ECM minimum $\mathrm{N}$ supply to plant } \\
\hline MIN $_{S U P L}$ & - & $0.1^{\mathrm{e}}$ & 0.9 \\
\hline \multicolumn{4}{|c|}{ Optimum ECM fungi $\mathrm{C}$ allocation fraction } \\
\hline FRAC $_{\mathrm{OPT}}$ & - & $0.1^{\mathrm{f}}$ & $0.3^{\mathrm{f}}$ \\
\hline \multicolumn{4}{|l|}{$\mathrm{N}$ sensitivity coefficient } \\
\hline NAVAIL $_{\text {COEF }}$ & - & 0.0001 & 0.001 \\
\hline
\end{tabular}

are not physically represented in the model. The rate of the organic $\mathrm{N}$ uptake is determined by the plant $\mathrm{N}$ demand and restricted by the availability of organic $\mathrm{N}$ in the soil humus pools (Eq. 4.4, 4.5; Table A1). Plants can also additionally take up ammonium and nitrate (Eq. 4.1, 4.2; Table A1). In the ECM explicit approach, ECM are fully physically considered as described above. ECM growth interacts dynamically with plant growth and responds to changes in soil $\mathrm{N}$ availability and soil temperature. ECM can take up both mineral and organic $\mathrm{N}$ forms.

\subsubsection{Simulated regions and database}

Simulations were performed for four forests sites - Lycksele, Mora, Nässjö, and Ljungbyhed - situated along a climate and $\mathrm{N}$ deposition gradient in Sweden (Fig. 2). Climate and site information is given in Table 3 and the climate data were taken from the Swedish Meteorological and Hydrological Institute (SMHI). Data on forest standing stock volumes and forest management were derived from the database and practical guidelines of the Swedish Forest Agency (2005) and applied as previously described by Svensson et al. (2008a). Soil C content as well as soil $\mathrm{C} / \mathrm{N}$ ratio, previously determined by Berggren Kleja et al. (2008) and Olsson et al. (2007), were used to describe soil properties in the initial model setup. For all simulated sites and modeling approaches, the development of managed Norway spruce forests was simulated in daily steps over a 100-year period from a newly established forest to a closed mature forest. Available daily climate data (1961-1986) were repeated four times in order to cover the entire period, and thus climatic warming effects are not considered here. A minimum of specific regional data including the meteorological data, $\mathrm{N}$ deposition, and soil data were used as input values (Table 3). Otherwise, model parameters were kept identical between modeling approaches in order to evaluate the general model applicability. An overview of the parameter values is shown in Table A1d in the Appendix. For a more detailed site description and CoupModel setup, see Svensson et al. (2008a).

\subsection{Brief description of Bayesian calibration}

\subsubsection{Observational constraints}

We performed a Bayesian calibration for all modeling approaches and sites. In this study, we emphasize the models' predictability in precisely describing the long-term plant and soil developments, also aiming at maximized model flexibility. This allows us to compare the different model approaches in terms of explaining the measured data and also to investigate distributions and uncertainty of key parameters. The previous modeling study by Svensson et al. (2008a) demonstrated that the changes of soil $\mathrm{C}$ at these sites were rather small over a 100-year period while the soil $\mathrm{C} / \mathrm{N}$ ratio showed large variabilities with different $\mathrm{N}$ supply assumptions. Therefore, in this study the measured $\mathrm{C} / \mathrm{N}$ ratio of soil organic matter and standing stock biomass were used as observational constraints. The measured error (also called relative uncertainty in Table 4) for both the soil $\mathrm{C} / \mathrm{N}$ ratio and the standing stock biomass were difficult to assume due to lack of information. An uncertainty estimate of $30 \%$ was generally recommended under such conditions (van Oijen et al., 2005). In order to reduce the weight of values close to zero on behalf of large peaks, a minimum measured error that is $10 \%$ of the measured value was defined in this study (Klemedtsson et al., 2008). This is also because our inten- 
Table 3. Climatic and soil data and initial settings of the four study soils applied in all model approaches.

\begin{tabular}{|c|c|c|c|c|c|c|c|c|c|}
\hline \multirow[b]{2}{*}{ Sites } & \multirow[b]{2}{*}{ Location } & \multirow[b]{2}{*}{$\begin{array}{l}\text { Altitude } \\
\text { (m a.s.l.) }\end{array}$} & \multicolumn{5}{|c|}{ Driving data } & \multicolumn{2}{|c|}{ Calibration data } \\
\hline & & & $\begin{array}{r}\text { Air } \\
\text { temperature } \\
\left({ }^{\circ} \mathrm{C}\right)\end{array}$ & $\begin{array}{r}\text { Precipitation }^{\mathrm{a}} \\
(\mathrm{mm})\end{array}$ & $\begin{array}{r}\mathrm{N} \text { deposition } \\
\left(\mathrm{kg} \mathrm{Nha}^{-1}\right. \\
\left.\mathrm{yr}^{-1}\right)\end{array}$ & $\begin{array}{r}\text { Soil C } \\
\left(\mathrm{g} \mathrm{C} \mathrm{m}^{-2}\right)\end{array}$ & $\begin{array}{r}\text { Soil N } \\
\left(\mathrm{g} \mathrm{N} \mathrm{m}^{-2}\right)\end{array}$ & Soil C / N & $\begin{array}{r}\text { Standing } \\
\text { stock }^{\mathrm{b}} \\
\left(\mathrm{g} \mathrm{C} \mathrm{m}^{-2}\right)\end{array}$ \\
\hline Lycksele & $64^{\circ} 59^{\prime} \mathrm{N}, 18^{\circ} 66^{\prime} \mathrm{E}$ & 223 & 0.7 & 613 & 1.5 & 7006 & 223 & 31.5 & 5371 \\
\hline Mora & $61^{\circ} 00^{\prime} \mathrm{N}, 14^{\circ} 59^{\prime} \mathrm{E}$ & 161 & 3.3 & 630 & 3.5 & 8567 & 295 & 29.1 & 7815 \\
\hline Nässjö & $57^{\circ} 64^{\prime} \mathrm{N}, 14^{\circ} 69^{\prime} \mathrm{E}$ & 305 & 5.2 & 712 & 7.5 & 9995 & 367 & 27.2 & 10443 \\
\hline
\end{tabular}

${ }^{a}$ The 30-year (1961-1991) annual average. ${ }^{\text {b }}$ According to Skogsdata for a 100-year-old forest (2003: http://www.slu.se/en/webbtjanster-miljoanalys/forest-statistics/skogsdata/)

Table 4. Prior values of variables used for model calibration and accepted relative uncertainty (a), and posterior model performance indicators (b): mean error (ME) between simulated and measured values, standard variation in ME (SD), and summed log likelihood of all accepted runs for simulated standing plant biomass $\left(\mathrm{g} \mathrm{C} \mathrm{m}^{-2}\right)$ and soil $\mathrm{C} / \mathrm{N}$ ratio after the 100-year simulation period.

\begin{tabular}{|c|c|c|c|c|c|c|c|c|}
\hline & \multirow[t]{2}{*}{ (a) } & \multicolumn{3}{|c|}{ Plant biomass $\left(\mathrm{g} \mathrm{C} \mathrm{m}^{-2}\right)$} & \multicolumn{4}{|c|}{ Soil C / N ratio } \\
\hline & & Mean & \multicolumn{2}{|c|}{ Relative uncertainty (\%) } & \multicolumn{2}{|c|}{ Mean } & \multicolumn{2}{|c|}{ Relative uncertainty (\%) } \\
\hline & Lycksele & 5371 & \multicolumn{2}{|c|}{10} & \multicolumn{2}{|c|}{32} & \multicolumn{2}{|c|}{10} \\
\hline & Mora & 7815 & \multicolumn{2}{|c|}{10} & \multicolumn{2}{|c|}{29.1} & \multicolumn{2}{|c|}{10} \\
\hline & Nässjö & 10443 & \multicolumn{2}{|c|}{10} & \multicolumn{2}{|c|}{27.2} & \multicolumn{2}{|c|}{10} \\
\hline & Ljungbyhed & 11501 & \multicolumn{2}{|c|}{10} & \multicolumn{2}{|c|}{19.8} & \multicolumn{2}{|c|}{10} \\
\hline \multirow[t]{2}{*}{ (b) } & & \multicolumn{3}{|c|}{ Plant biomass $\left(\mathrm{g} \mathrm{C} \mathrm{m}^{-2}\right)$} & \multicolumn{3}{|c|}{ Soil C / N ratio } & \multirow[t]{2}{*}{ Runs accepted (\%) } \\
\hline & & $\mathrm{ME}$ & SD & Log-like & $\mathrm{ME}$ & SD & Log-like & \\
\hline \multirow{4}{*}{ Nonlim } & Lycksele & 37.6 & 531.1 & -7.7 & -5.8 & 1.3 & -3.8 & 25 \\
\hline & Mora & 38.7 & 1098.2 & -8.4 & -3.9 & 1.4 & -3.0 & 41 \\
\hline & Nässjö & 42.2 & 1021.3 & -8.3 & -2.7 & 1.6 & -2.6 & 48 \\
\hline & Ljungbyhed & 1.0 & 1155.6 & -10.2 & 0.3 & 1.8 & -2.1 & 48 \\
\hline \multirow{4}{*}{ Implicit } & Lycksele & -107.2 & 535.0 & -7.7 & -1.1 & 3.3 & -2.7 & 42 \\
\hline & Mora & -98.3 & 787.1 & -8.1 & -1.1 & 2.7 & -2.5 & 45 \\
\hline & Nässjö & -86.0 & 1036.2 & -8.0 & -1.0 & 2.5 & -2.4 & 46 \\
\hline & Ljungbyhed & 100.1 & 1143.2 & -8.5 & 0.5 & 1.6 & -2.0 & 50 \\
\hline \multirow{4}{*}{ Explicit } & Lycksele & -162.3 & 534.9 & -7.7 & -0.5 & 3.4 & -2.7 & 29 \\
\hline & Mora & -215.4 & 809.1 & -8.2 & -0.3 & 2.7 & -2.4 & 32 \\
\hline & Nässjö & -222.3 & 1041.2 & -8.1 & 0.0 & 2.5 & -2.3 & 30 \\
\hline & Ljungbyhed & -139.0 & 1137.6 & -8.5 & 1.0 & 1.7 & -2.1 & 32 \\
\hline
\end{tabular}

tion was to force the model to simulate tree biomass and soil C / $\mathrm{N}$ ratio precisely to better constrain posterior parameter distributions for the respective model approach and site. The Bayesian calibration as applied in this study is briefly described below; however, for a detailed description of the general methodology see Klemedtsson et al. (2008) and van Oijen et al. (2005), for example.

\subsubsection{Model parameters chosen for calibration}

The different ECM modeling approaches were calibrated for a comprehensive set of key parameters, which are chosen according to their function as regulating factors of the $\mathrm{C}$ and $\mathrm{N}$ fluxes in the plant-soil-mycorrhiza continuum (Table 2). In the nonlim approach, the constant $\mathrm{N}$ supply parameter Con-
stantNsupply for the spruce tree was a calibration parameter. In the implicit approach, the fraction of organic $\mathrm{N}$ available for plant uptake (NUPT ORGFRACMAX) was included in the calibration based on Svensson et al. (2008a). For the ECM explicit approach, all ECM fungal parameters in MYCOFON including ECM growth ( $\mathrm{C}$ and $\mathrm{N}$ assimilation and uptake, $\mathrm{C}$ and $\mathrm{N}$ losses), overall $\mathrm{N}$ uptake and plant $\mathrm{N}$ supply, respiration, and littering were calibrated. For all three approaches, the humus decomposition rate $\left(K_{\mathrm{H}}\right)$, the $\mathrm{C} / \mathrm{N}$ ratio of microbes $\left(\mathrm{CN}_{\text {mic }}\right)$ regulating soil mineralization and thus soil $\mathrm{N}$ availability, and the fraction of plant $\mathrm{C}$ assimilates allocated to the rooting zone $\left(F_{\text {ROOT }}\right)$ regulating ECM fungal growth were additionally calibrated. 


\subsubsection{Bayesian calibration of models}

The prior distributions of the parameters were chosen as uniform and uncorrelated, with wide ranges of possible values (Table 2). Bayesian calibration combines the prior information about the parameters and the observational constraints on model outputs to obtain a revised probability distribution called posterior distribution (Yeluripati et al., 2009). The posterior probability of any parameter vector is proportional to the product of its prior probability and its corresponding likelihood (Eq. 1). The likelihood function that determines acceptance of the parameter sets as the posterior distributions is based on the assumption that the model errors (the differences between simulated and observed values) are normally distributed and uncorrelated (van Oijen et al., 2005). Furthermore, model errors are assumed to be additive so that the $\log$-likelihood function reads

$\log L=$

$\sum_{i=1}^{n}\left(-0.5\left(\frac{y_{i}-f\left(\boldsymbol{\omega}_{i} \cdot \boldsymbol{\theta}_{i}\right)}{\sigma_{i}}\right)-0.5 \cdot \log (2 \pi)\right)-\log \left(\sigma_{i}\right)$,

where $y_{i}$ is observed values, $f\left(\boldsymbol{\omega}_{i} \cdot \boldsymbol{\theta}_{i}\right)$ is simulated values for a given model input vector $\boldsymbol{\omega}_{i}$ and parameter set $\boldsymbol{\theta}_{i}, \sigma_{i}$ is standard deviation across the measured replicates, and $n$ is number of variables measured.

To construct the posterior parameter distribution, many sets of parameter $\theta$ were sampled. In this study, candidate parameter sets were generated using the Metropolis-Hastings random-walk Markov chain Monte Carlo (MCMC) algorithm (van Oijen et al., 2005; Vrugt, 2016). Briefly, a parameter ensemble of "walkers" move around randomly and the integrand value at each step was calculated. A few number of tentative steps may further be made to find a parameter space with high contribution to the integral. MCMC thus increases the sampling efficiency by using information about the shape of the likelihood function to preferentially sample in regions where the posterior probability is high (Rubinstein and Kroese, 2016). For each simulation, the model's likelihood was evaluated for a certain parameter set. After each run, a new parameter set was generated by adding a vector of random numbers $\varepsilon$ to the previous parameter vector:

$\boldsymbol{\theta}_{i+1}=\boldsymbol{\theta}_{i}+\varepsilon$,

where $\boldsymbol{\theta}_{i}$ is the previous parameter vector, $\boldsymbol{\theta}_{i+1}$ the new parameter vector, and $\varepsilon$ random numbers.

The normally distributed random numbers $\varepsilon$ have a mean of zero and a step length of 0.05 , i.e., $5 \%$ of the prior parameter range as proposed by van Oijen et al. (2005). After a sufficiently long iteration (referred to as the "burn-in" period), the Markov chain reaches a stationary distribution that converges to the joint parameter posterior (Ricciuto et al., 2008). Van Oijen et al. (2005) recommended chain lengths in the order of $10^{4}-10^{5}$ for modeling forest ecosystems with many observational constraints. In this trial study, we performed $10^{4}$ runs for each ECM modeling approach and site. This is because a length of $10^{4}$ model runs with a burn-in length of around $10^{3}$ runs results in numerically stable results for our current considered problem. The step sizes used in this study result in acceptance rates between 25 and $50 \%$ (Table 4), which is also generally the most efficient range for the MCMC algorithm (Harmon and Challenor, 1997).

\section{Results}

\subsection{Comparison of the three modeling approaches}

\subsubsection{General ability to reproduce tree growth and soil $\mathbf{C} / \mathbf{N}$}

The three modeling approaches show different accuracies in reproducing current plant growth and soil $\mathrm{C} / \mathrm{N}$ ratio after calibration (Table $4 \mathrm{~b}$ ). The posterior model in the implicit and explicit approaches shows better performance of simulating soil $\mathrm{C}$ and $\mathrm{N}$, as indicated by the soil $\mathrm{C} / \mathrm{N}$ ratio, than the nonlim approach. The latter tends to simulate a lower soil $\mathrm{C} / \mathrm{N}$ ratio, indicated by the negative mean errors (ME, difference between the simulated and measured values) in the posterior model (Table $4 \mathrm{~b}$ ). The ME by the nonlim approach is also 2 to 5 times higher than that when using the implicit or explicit approach (Table 4b). The nonlim approach tends to overestimate plant growth as the posterior mean of $\mathrm{ME}$ for plant $\mathrm{C}$ is always positive, while the implicit and explicit approaches tend to show an underestimation (Table 4b).

All posterior models underestimate soil $\mathrm{C} / \mathrm{N}$ for the northern sites, which are generally more $\mathrm{N}$ limited, but gradually switch to overestimation at the southern sites. The model with the nonlim approach simulates better plant growth for the southernmost site, Ljungbyhed, than the other sites. Further, modeled plant growth at Ljungbyhed is overestimated by the implicit approach but underestimated when the explicit approach is used (Table $4 \mathrm{~b}$ ). The acceptance of model runs in posterior is higher for the nonlim ( 25 to $48 \%$ ) and implicit approaches (42 to $50 \%$ ), followed by the explicit approach (30 to $33 \%$ ). No major differences are found for the summed log likelihood for both calibration variables (Table $4 \mathrm{~b})$.

\subsubsection{Ecosystem $\mathrm{N}$ and $\mathrm{C}$ fluxes and comparison to measured data}

Modeled major ecosystem $\mathrm{N}$ fluxes in the posterior are shown in Fig. 3. The modeled N litterfall, uptake, and leaching fluxes differ significantly from one modeling approach to another, where the nonlim approach always gives the highest fluxes. The explicit and implicit approaches show similar modeled $\mathrm{N}$ fluxes for the northernmost site, Lycksele. However, the differences between these two approaches become larger when moving south where higher fluxes are simulated 


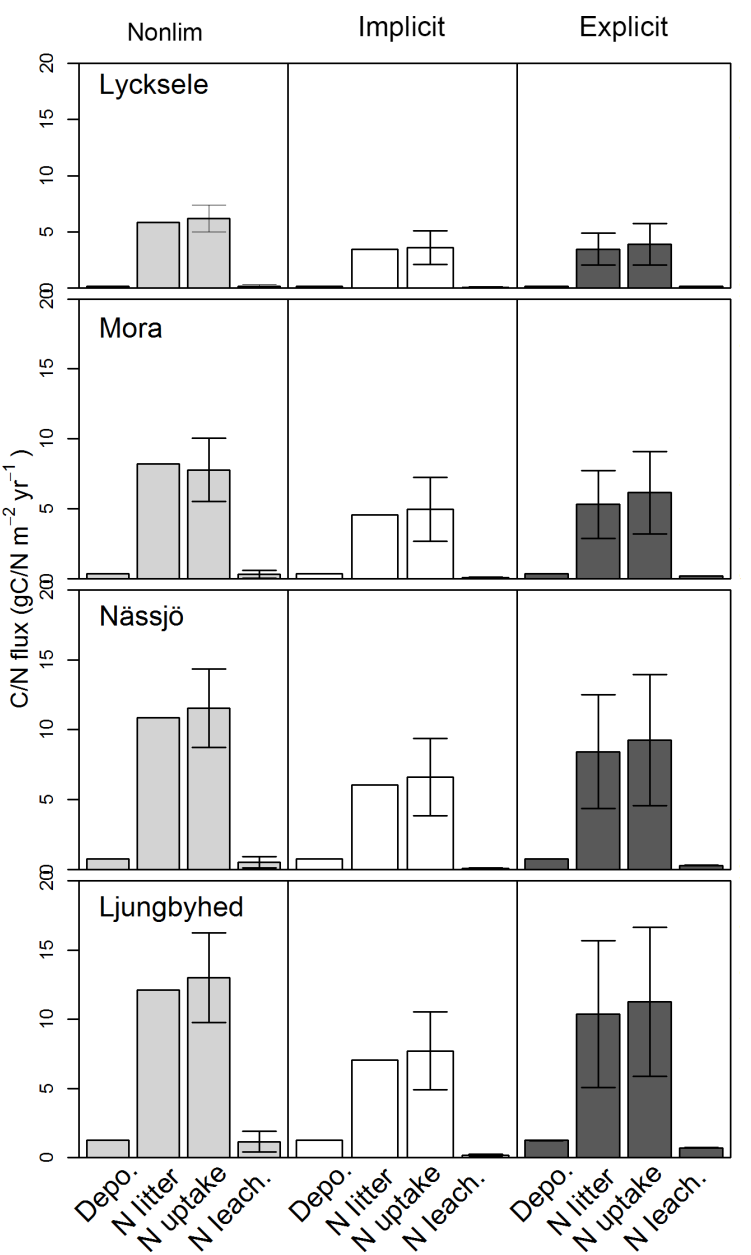

Figure 3. Soil $\mathrm{N}$ fluxes for the nonlim (grey columns), implicit (white), and explicit (black) model approaches; same color scheme used for the other figures. Presented are the major $\mathrm{N}$ inputs ( $\mathrm{N}$ deposition, total $\mathrm{N}$ litter production, added to the soil litter pool by fresh litter), and outputs (N uptake from the plant or ECM, N leaching). Error bars indicate the 90th percentile of accepted model runs (posterior). Units for $\mathrm{N}_{\text {are }} \mathrm{g} \mathrm{N} \mathrm{m}^{-2} \mathrm{yr}^{-1}$ and $\mathrm{g} \mathrm{C} \mathrm{m}^{-2} \mathrm{yr}^{-1}$ for $\mathrm{C}$.

by the explicit approach (Fig. 3). For instance, modeled $\mathrm{N}$ litter production in the explicit approach increases by 1 to $30 \%$ compared to the implicit approach, but $\mathrm{N}$ losses due to uptake and leaching also increase by 10 to $50 \%$ for Lycksele and Ljungbyhed, respectively (Fig. 3). The modeled N pool sizes for these two sites also differ, where the explicit approach shows a larger mineral $\mathrm{N}$ in the soil and a smaller organic $\mathrm{N}$ pool compared to the implicit approach (Fig. 4).

Figure 5 shows the modeled major ecosystem $C$ fluxes and comparison with previous results by Svensson et al. (2008a) and measured data from three other Swedish sites (Flakaliden, Knottåsen, and Åsa ; Fig. 2) at comparable latitudes and on comparable soils by Lindroth et al. (2008). The simulated plant gross primary production (GPP) using three approaches all show an increasing trend from the northern sites to the

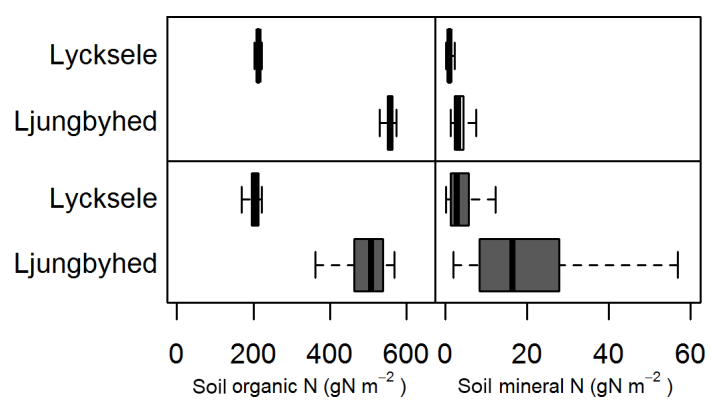

Figure 4. Average soil organic and mineral content in the implicit ECM model (upper graph) and explicit ECM model (lower graph) for the two sites Lycksele and Ljungbyhed. Box plots indicate the median (bold line), the 25th and 75th percentiles (bars), and the 10th and 90th percentiles (whiskers).

southern sites due to a more favorable climates and $\mathrm{N}$ availability for spruce forest growth. For the studied four sites, the nonlim approach simulates the highest GPP followed by the explicit approach and lastly the implicit approach. The variation in modeled GPP between the explicit and implicit approach ranges from $12 \%$ at northernmost Lycksele site to $7 \%$ at the southernmost Ljungbyhed site (Fig. 5). Simulated GPP in this study is generally higher than that by Svensson et al. (2008a) but comparable with the measured data from Lindroth et al. (2008). It should be noted that the GPP at the southern site, Åsa, was only measured for 1 year and thus can show large uncertainties due to annual variations. Modeled ecosystem respiration generally follows the pattern of GPP. The net ecosystem exchange (NEE) values predicted by the three approaches all show an overall atmospheric $\mathrm{C}$ uptake for all the sites where the explicit approach seems to have a higher uptake strength than the others (Fig. 5). Current estimates of NEE are again within the measured range by Lindroth et al. (2008), although a small net release of C was measured at Knottåsen, likely caused by the abnormal high temperature during those measured years. In addition, explicitly including ECM also increases the soil respiration for the four sites except the northernmost Lycksele site. The simulated ranges are however somehow smaller than those by Svensson et al. (2008a).

The nonlim approach generally shows much higher uncertainties in the modeled $\mathrm{N}$ fluxes than either the implicit or explicit approaches. The nonlim approach simulated soil $\mathrm{N}$ sequestration of up to $2 \mathrm{~g} \mathrm{~N} \mathrm{~m}^{-2} \mathrm{yr}^{-1}$ for all the sites, but values much lower or close to zero were found when using the other two modeling approaches (Fig. 5). The simulated soil $\mathrm{C}$ balance by the nonlim approach also contrasts with that of soil $\mathrm{N}$, in which the soil sequesters $\mathrm{C}$ at the northernmost site, Lycksele, but loses $\mathrm{C}$ at a rate of 6 to $17 \mathrm{~g} \mathrm{C} \mathrm{m}^{-2} \mathrm{yr}^{-1}$ for the other three sites (Fig. 5). Therefore, soil $\mathrm{C}$ and $\mathrm{N}$ are not in steady state and are decoupled in the nonlim approach over the simulated 100-year period. The implicit and explicit approaches, however, show a strong coupling between soil 
$\operatorname{GPP}\left(\mathrm{g} \mathrm{C} \mathrm{m}^{-2} \mathrm{yr}^{-1}\right)$

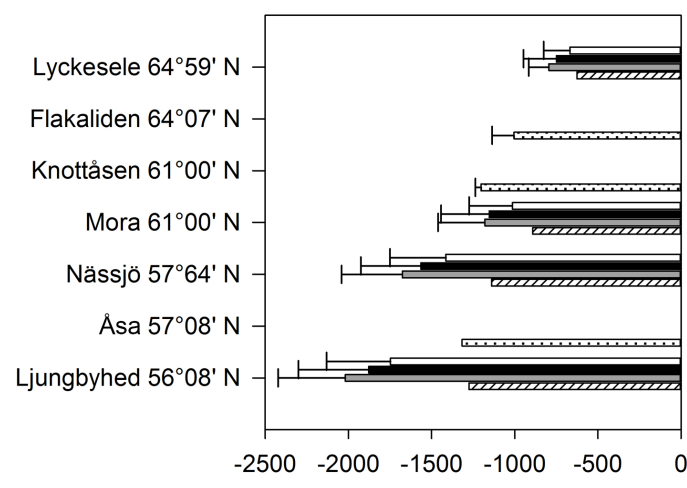

NEE $\left(\mathrm{g} \mathrm{C} \mathrm{m}^{-2} \mathrm{yr}^{-1}\right)$

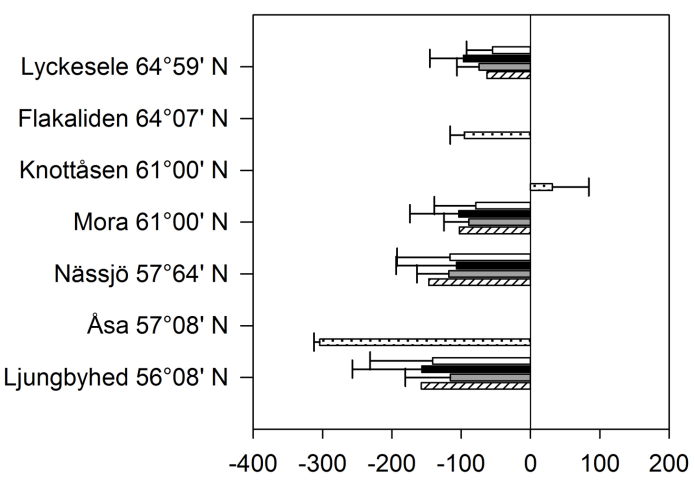

Change in soil $\mathrm{C}$

$\left(\mathrm{g} \mathrm{C} \mathrm{m} \mathrm{yr}^{-1}\right)$

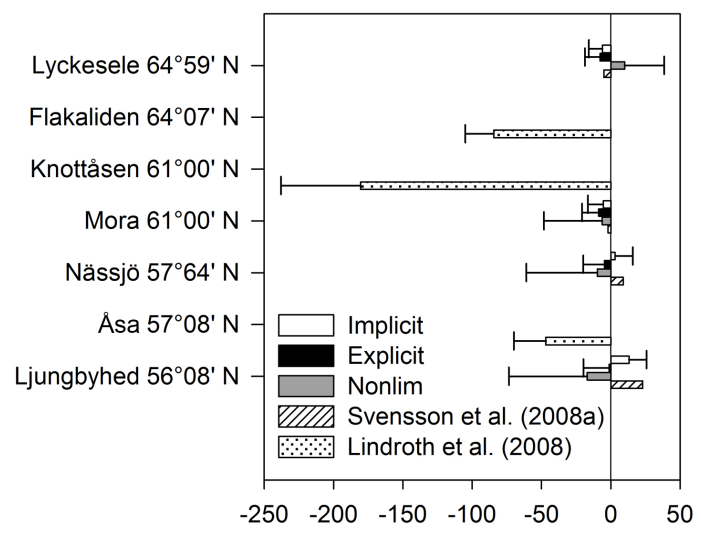

Ecosystem respiration

$\left(\mathrm{gC} \mathrm{m}^{-2} \mathrm{yr}^{-1}\right)$

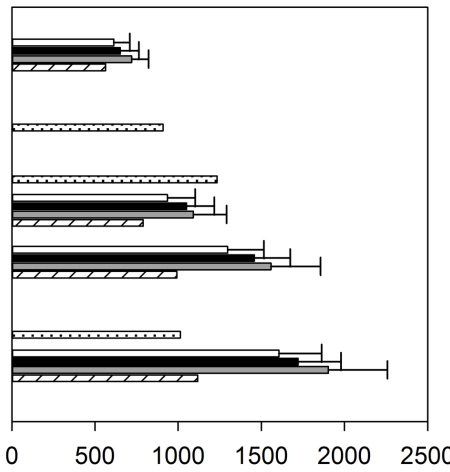

Total soil respiration

$\left(\mathrm{g} \mathrm{C} \mathrm{m} \mathrm{mr}^{-1}\right)$

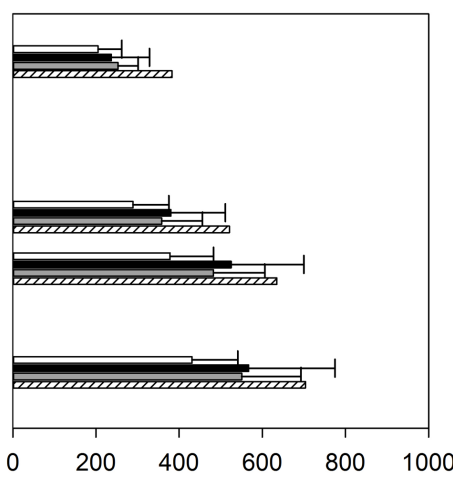

Change in soil $\mathrm{N}$

$\left(\mathrm{g} \mathrm{N} \mathrm{m} \mathrm{yr}^{-1}\right)$

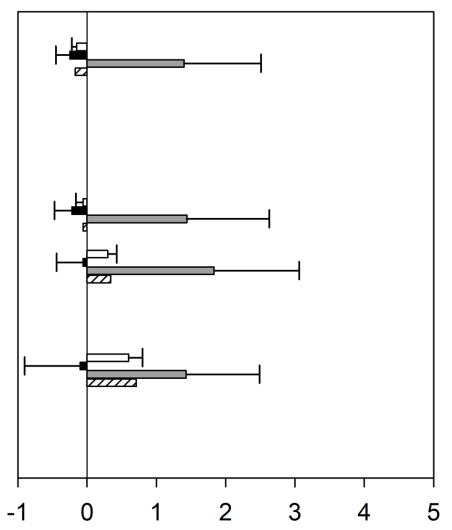

Figure 5. Simulated GPP, ecosystem respiration, NEE, soil respiration, change in soil C, and change in soil $\mathrm{N}$ for all four sites with the three ECM modeling approaches and also compared with modeled data by Svensson et al. (2008a) and measurements by Lindroth et al. (2008).

$\mathrm{C}$ and N (Fig. 5). That is, for the implicit approach, Lycksele and Mora soils lose 6 and $5 \mathrm{~g} \mathrm{C} \mathrm{m}^{-2} \mathrm{yr}^{-1}$, respectively, while Nässjö and Ljungbyhed soils gain 3 and $13 \mathrm{~g} \mathrm{C} \mathrm{m}^{-2} \mathrm{yr}^{-1}$, respectively. Similarly, Lycksele and Mora lose $\mathrm{N}$ by 0.2 and $0.1 \mathrm{~g} \mathrm{~N} \mathrm{~m}^{-2} \mathrm{yr}^{-1}$, while Nässjö and Ljungbyhed gain $\mathrm{N}$ by
0.3 and $0.6 \mathrm{~g} \mathrm{~N} \mathrm{~m}^{-2} \mathrm{yr}^{-1}$. For the explicit approach, soil $\mathrm{C}$ and $\mathrm{N}$ losses at the two northern sites are slightly higher than those in the implicit approach. The respective net change in the soil $\mathrm{C}$ and $\mathrm{N}$ pools of the implicit approach corresponds well to the results by Svensson et al. (2008a), who also sug- 


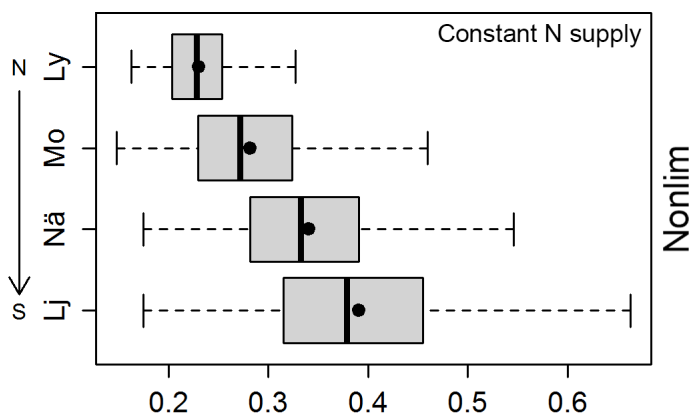

at the southern sites to explain the observed tree biomass and soil $\mathrm{C} / \mathrm{N}$ ratio. No significant differences in parameter values - microbial $\mathrm{C} / \mathrm{N}$ ratio $\left(\mathrm{CN}_{\mathrm{MIC}}\right)$, humus decomposition coefficient $\left(K_{\mathrm{H}}\right)$, and the fraction of $\mathrm{C}$ allocated to roots $\left(F_{\mathrm{ROOT}}\right)$ in the nonlim approach are found for the different sites (data not shown). The organic $\mathrm{N}$ uptake parameter in the

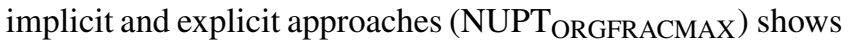
an opposite pattern with the highest values for Lycksele and lowest for Ljungbyhed and larger parameter uncertainties are found for the explicit approach (Fig. 6). Parameter values for the northern sites also have a much wider range compared with the southern sites (Fig. 6), which also explains the larger simulated ME of soil $\mathrm{C} / \mathrm{N}$ at the northern sites (Table 4). Both approaches demonstrate that the plant and soil conditions at the northern sites could not be simulated without an enhanced uptake of organic $\mathrm{N}$.

When the implicit approach is used, the posterior humus decomposition coefficient $K_{\mathrm{H}}$ shows higher values for the northern sites and decreases along the studied transect, demonstrating a modeled enhancement of organic matter decomposition and soil mineralization for northern sites (Fig. 7). A less-clear tendency towards higher values at the southern sites is identified for the fraction of $\mathrm{C}$ allocated to roots, the $F_{\text {ROOT }}$ parameter. The microbial $\mathrm{C} / \mathrm{N}$ ratio $\left(\mathrm{CN}_{\mathrm{MIC}}\right)$ parameter for both implicit and explicit approaches show similar posterior distributions for the three northern sites. However, much lower values are obtained for the southernmost Ljungbyhed site (Fig. 7), reflecting a more N-rich soil environment. Overall, parameters are less constrained and only minor differences among sites are found when the explicit approach is used (Fig. 7).

ECM model approaches. Distributions are presented as box plots over the prior range of variation (corresponding to the range on the $x$ axis). Box plots depict the median (bold line), the 25th and 75th percentiles (bars), and the 10th and 90th percentiles (whiskers).

gest a small loss of soil $\mathrm{C}$ in the north, whereas soils in the south gain C. However, when the explicit approach is used, the soils in the south are also predicted to lose $\mathrm{C}$ and N. Lindroth et al. (2008) found a similar trend in the soil net C change as simulated by the explicit approach here, but with a higher loss rate between 24 and $133 \mathrm{~g} \mathrm{C} \mathrm{m}^{-2} \mathrm{yr}^{-1}$ (Fig. 5). Overall, our results show that accounting for ECM in boreal forest ecosystems can have a considerable impact on the predicted $\mathrm{C}$ and $\mathrm{N}$ dynamics for both the plants and soil.

\subsection{Posterior parameter distributions}

\subsubsection{Posterior distributions of common parameters}

The posterior distributions differ from the prior uniform distributions for all modeling approaches and parameters, reflecting the efficiency of Bayesian calibration (Figs. 6 and 7). The posterior constantNsupply parameter in the nonlim approach shows the lowest values at Lycksele and the highest at Ljungbyhed. This means a higher $\mathrm{N}$ supply is necessary

\subsubsection{ECM fungal-specific parameters}

The posterior distributions of all ECM fungal-specific parameters are constrained to log-normal or normal distributions (data not shown). The mean values of $\mathrm{N}$ uptake parameters $\left(\mathrm{NORG}_{\mathrm{RATE}}, \mathrm{NH}_{4_{\mathrm{RATE}}}, \mathrm{NO}_{3_{\text {RATE }}}\right.$ ) show a decreasing trend from the northern to southern sites (Fig. 8). This again means an enhanced ECM fungal $\mathrm{N}$ uptake is necessary to explain the observed soil and plant data at the more $\mathrm{N}$ limited northern sites. Similarly, lower values for the northern regions and higher values for the southern regions are also found for the minimum ECM fungal $\mathrm{C} / \mathrm{N}$ ratio parameter $\left(\mathrm{CN}_{\mathrm{FMIN}}\right)$. The optimum ratio between $\mathrm{ECM}$ and root $\mathrm{C}$ content, FRAC $\mathrm{OPT}_{\mathrm{OPT}}$, tends to be higher at the northern sites and lower at the southern sites, also implying a higher modeled ECM biomass at the northern sites (Fig. 8). MIN SUPL, $_{\text {, }}$ the minimum supply of $\mathrm{N}$ from ECM to the host plant parameter, does not show a clear trend. Further, differences in the other ECM parameters for the four sites are minor (Fig. 8). 


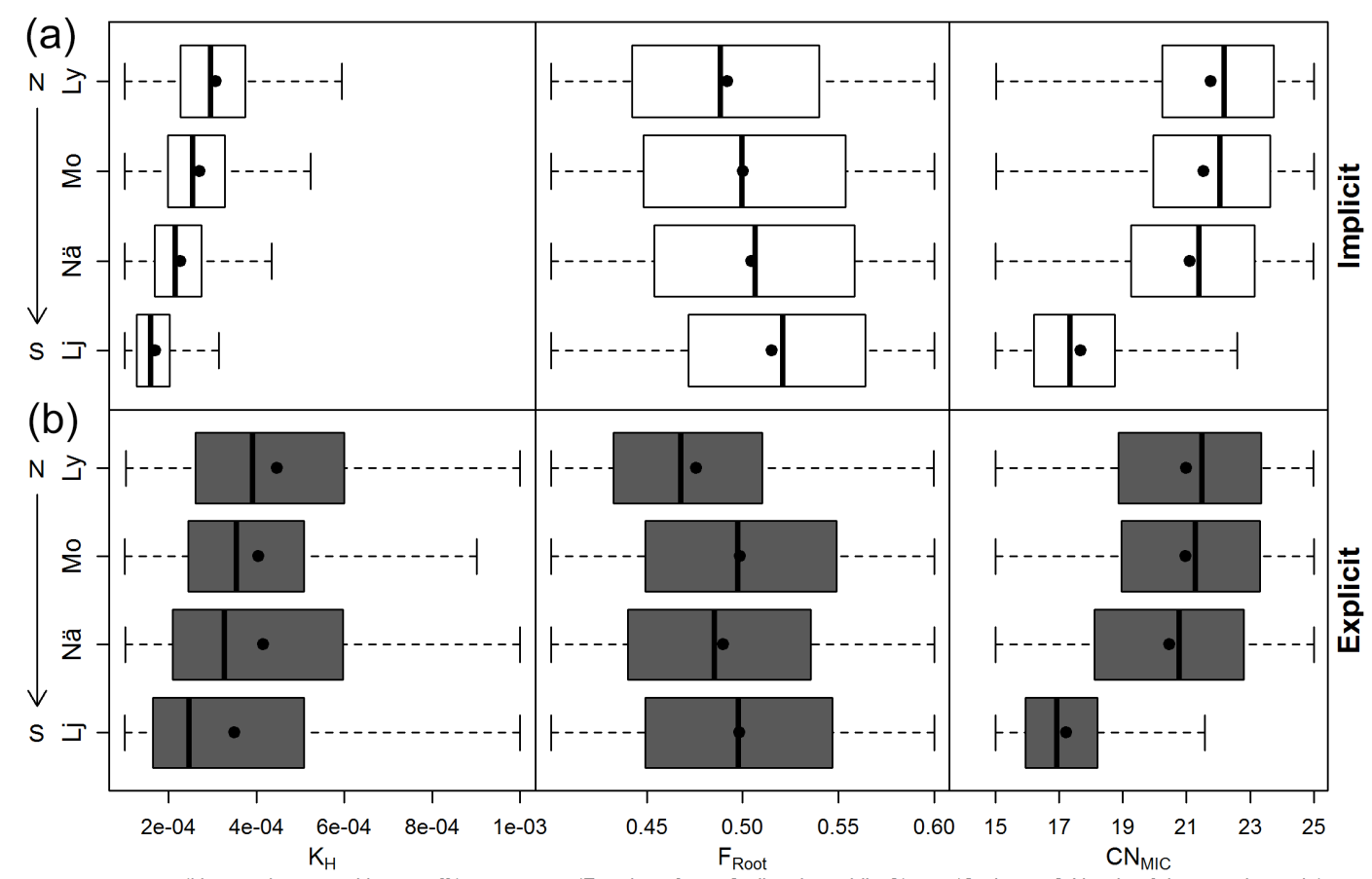

(Humus decomposition. coeff.)

(Fraction of root $\mathrm{C}$ alloc. in mobile $\mathrm{C}$ )

(Optimum C: $\mathrm{N}$ ratio of decomp. bacteria)

Figure 7. Posterior parameter distributions for common parameters using the implicit (a: white) and explicit (b: black) ECM approaches for four different sites from north to south. Distributions are presented as box plots over the prior range of variation (corresponding to the range on the $x$ axis). Box plots depict the median (bold line), the 25th and 75th percentiles (bars), and the 10th and 90th percentiles (whiskers). The parameters shown are $K_{\mathrm{H}}$ the humus decomposition coefficient, $F_{\text {Root }}$ the fraction of $\mathrm{C}$ assimilates distributed to the roots, ECM, and $\mathrm{CN}_{\mathrm{MIC}}$ the microbial $\mathrm{C} / \mathrm{N}$ ratio.

\subsubsection{Correlation between parameters}

An overview of correlations for all posterior model parameters can be found in Tables A2, A3, and A4. Key parameter sets showing correlation with each other (defined here as a Pearson correlation coefficient $r \geq 0.3$ or $\leq-0.3$ ) are shown in Fig. 9. When the implicit approach is used, a significant positive correlation is obtained between the humus decomposition rate, $K_{\mathrm{H}}$, and the fraction of $\mathrm{C}$ allocated to the rooting zone, $F_{\text {ROOT }}$. The organic $\mathrm{N}$ uptake parameter, NUPT ORGFRACMAX, and microbial $\mathrm{C} / \mathrm{N}$ ratio, $\mathrm{CN}_{\text {MIC }}$, are significantly negatively correlated, except for a weak correlation for Ljungbyhed (Fig. 9). A weak correlation between NUPT ${ }_{\text {ORGFRACMAX }}$ and $F_{\text {ROOT }}$ is also found for the Nässjö site (Table A2). For the explicit approach, the correlation coefficients between $K_{\mathrm{H}}$ and $F_{\mathrm{ROOT}}$ are decreased, and there is also a weaker correlation between NUPTORGFRACMAX and $\mathrm{CN}_{\mathrm{MIC}}$ for all sites compared to the implicit approach (Fig. 9). No clear correlation between common and ECM fungal parameters is obtained. Further, a negative correlation occurred among microbial $\mathrm{C} / \mathrm{N}$ ratio, $\mathrm{CN}_{\mathrm{MIC}}$, and the fungal $\mathrm{N}$ uptake rates $\left(\operatorname{Norg}_{\mathrm{RATE}}, \mathrm{NH}_{4_{\text {RATE }}}, \mathrm{NO}_{3_{\text {RATE }}}\right.$ ), but only for the northern sites Lycksele and Mora (Table A4). A moderate correlation is found for $K_{\mathrm{H}}$ and the fungal litter rate, $L$, for Ljungbyhed. Among fungal parameters, the $\mathrm{N}$ uptake rates moderately correlate to the litter production rate, $L$, at the northern sites, but correlations at Nässjö and Ljungbyhed are either weak or nonexistent (Table A4).

\section{Discussion}

Our new version of the CoupModel provides a detailed predictive model framework to explicitly account for ECM in the plant-soil-ECM continuum. Model comparison to two simpler ECM modeling approaches shows large variations in $\mathrm{N}$ dynamic simulations and that ECM and organic $\mathrm{N}$ uptake have to be included in ecosystem models to be able to describe the long-term plant and soil $\mathrm{C}$ and $\mathrm{N}$ development. Our results confirm that ECM have a substantial effect on soil $\mathrm{C}$ and $\mathrm{N}$ storage and can also impact forest plant growth. But more importantly, including them in ecosystem models is both important and feasible.

\subsection{Comparison of the three ECM modeling approaches}

The nonlim approach in this study shows an overestimation of plant growth and also larger biases in soil $\mathrm{N}$ than the implicit and explicit approaches even after calibration (Table 4). Soil $\mathrm{N}$ is expected to reach a steady state over a period of 

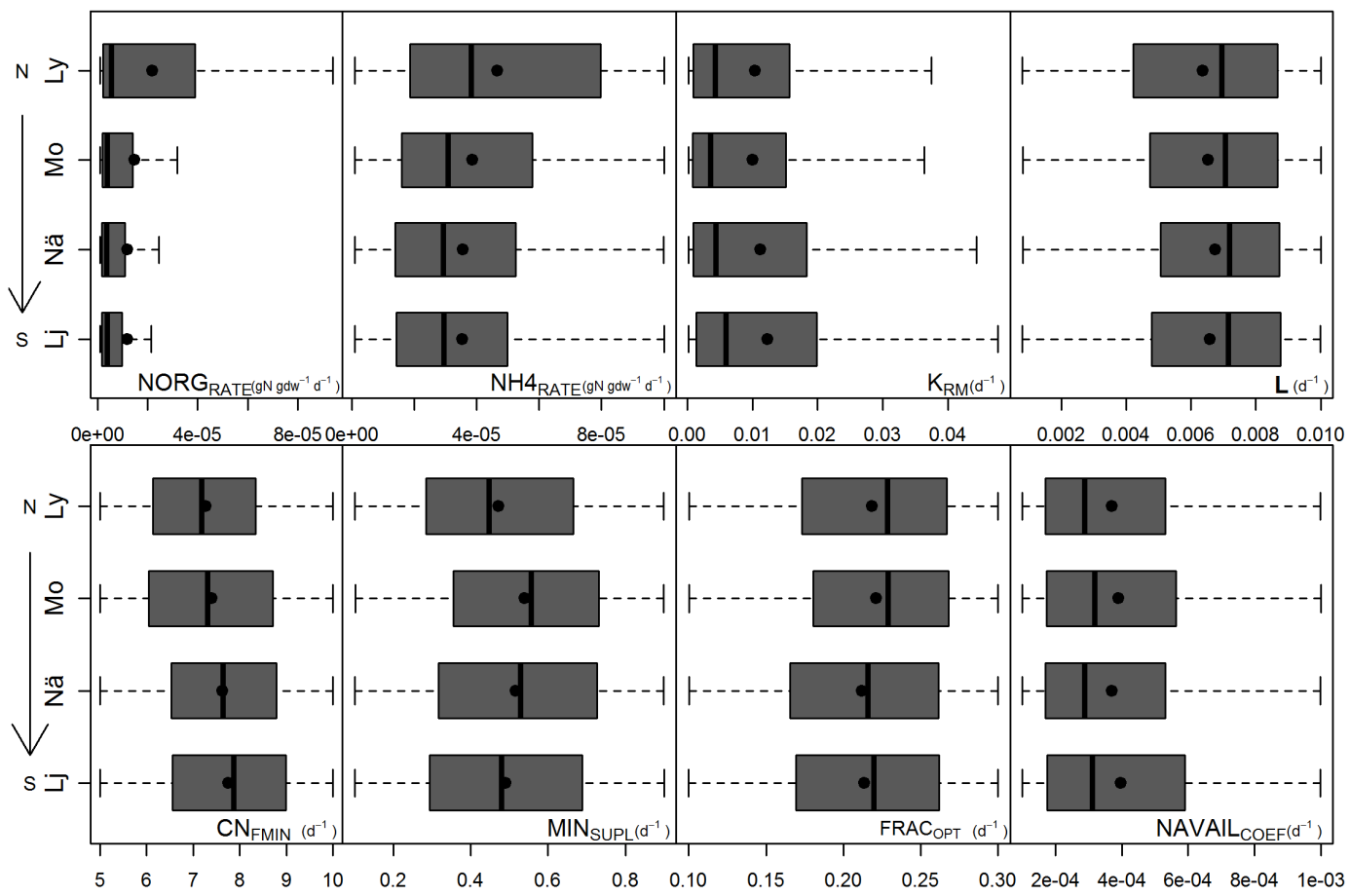

Figure 8. Posterior parameter distributions of ECM fungal-specific parameters (from top left to bottom right): organic $\mathrm{N}$ uptake rate $\left(\mathrm{NORG}_{\mathrm{RATE}}\right)$, ammonium uptake rate $\left(\mathrm{NH}_{4_{\mathrm{RATE}}}\right)$, respiration coefficient $\left(K_{\mathrm{RM}}\right)$, ECM fungal litter rate coefficient (the rate at which mycelia and mantle die and add to the soil litter pool, $L)$, minimum ECM fungal $\mathrm{C} / \mathrm{N}$ ratio $\left(\mathrm{CN}_{\mathrm{FMIN}}\right)$, ECM minimum $\mathrm{N}$ supply to plant $(\mathrm{MIN}$ SUPL $)$, optimum ratio between $\mathrm{ECM}$ and root $\mathrm{C}$ content (FRAC $\mathrm{OPT}_{\mathrm{OPT}}$ ), and $\mathrm{N}$ sensitivity coefficient (NAVAIL $\mathrm{COEF}$ ). Distributions are presented as box plots over the prior range of variation (corresponding to the range on the $x$ axis). Box plots depict the median (bold line), the mean (black point), the 25 th and 75 th percentiles (bars), and the 10th and 90 th percentiles (whiskers).

100 years (Svensson et al., 2008a). Therefore, the nonlim approach largely overestimates soil $\mathrm{N}$ sequestration, which can be attributed to the assumed "virtual" constant $\mathrm{N}$ uptake from the unlimited source. According to our model predictions, this virtual $\mathrm{N}$ fraction accounts for 20 to $30 \%$ of the total plant $\mathrm{N}$ uptake. A previous CoupModel application by $\mathrm{Wu}$ et al. (2012) demonstrated that the nonlim approach could possibly describe short-term $\mathrm{C}$ and water dynamics for a Finnish forest site. The same nonlim approach was also used in Franklin et al. (2014) to simulate Swedish forest biomass growth and its competition with ECM. This seems to suggest that plant growth and the $\mathrm{C}$ cycle can be simulated reasonably with the nonlim approach, although a slight trend of overestimation is exhibited. However, our modeling exercise further indicates that in this simplified approach soil $\mathrm{C}$ and $\mathrm{N}$ are uncoupled (Fig. 5), and therefore this approach is not recommended for future long-term soil $\mathrm{C}$ and $\mathrm{N}$ predictions. This is also reflected in the posterior model parameter distributions in which the constantNSupply rate parameter shows primary control on the modeled plant growth and soil conditions. Other parameters have minor or no importance for the model results, reflecting an oversimplified model structure of $\mathrm{N}$. Thus, the following discussion focuses on the other two modeling approaches.
Moore et al. (2015) demonstrated that accounting for ECM in ecosystem models would substantially affect soil C storage, and that the impact is largely dependent on plant growth. Our study additionally shows that ECM representation in ecosystem models could further feed back into the predicted plant growth through N. When ECM are implicitly included, the model simulates a plant biomass $48 \mathrm{~g} \mathrm{C} \mathrm{m}^{-2}$ (average of four sites, $\pm \mathrm{SD}$ : 86 ) lower compared to the measured data. When they are explicitly included, the difference becomes even larger, $185( \pm 35) \mathrm{g} \mathrm{C} \mathrm{m}^{-2}$ (Table 4). Including ECM explicitly in the model therefore results in decreased plant growth. This somehow differs from the general assumption that growth should be higher in mycorrhized plants, i.e., boreal forest trees, due to optimized nutrient supply (Pritsch et al., 2004; Finlay et al., 2008, see also review by Smith and Read, 2008). This discrepancy can possibly be due to (1) an enhanced root litterfall due to a higher turnover of ECM mycelia. Simulated litter production is 50 to $110 \mathrm{~g} \mathrm{C} \mathrm{m}^{-2} \mathrm{yr}^{-1}$ higher with the explicit approach compared to the implicit approach. This could be explained by conceptually considering the ECM implicitly in the roots where the litterfall rate of roots is about 3 times lower than that of ECM (calibrated litter rate of ECM is $0.0075 \mathrm{~d}^{-1}$, Fig. 8, whereas the litter rate of roots is $0.0027 \mathrm{~d}^{-1}$, Ta- 


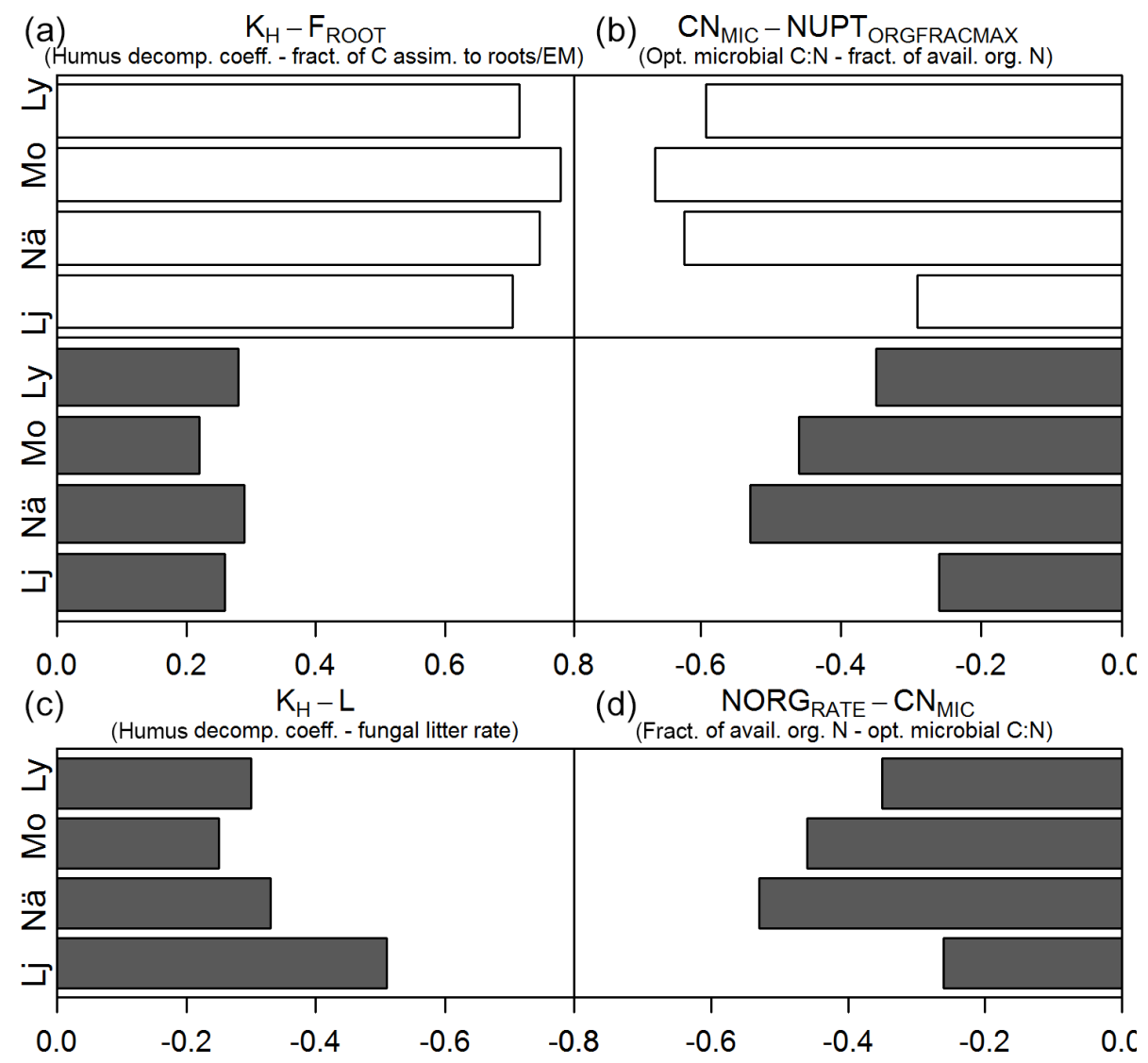

Figure 9. Correlation between model parameters, given as the Pearson correlation coefficient, for the implicit (white) and explicit ECM (black) approaches. (a) Correlation between humus decomposition coefficient $\left(K_{\mathrm{H}}\right)$ and the fraction of $\mathrm{C}$ assimilates (GPP) directed to ECM and roots $\left(F_{\mathrm{ROOT}}\right)$. (b) $\mathrm{C} / \mathrm{N}$ of microbes $\left(\mathrm{CN}_{\mathrm{MIC}}\right)$ and fraction of organic $\mathrm{N}$ available for uptake (NUPT ${ }_{\text {ORGFRACMAX). Correlation }}$ between ECM fungal parameters includes (c) humus decomposition coefficient $\left(K_{\mathrm{H}}\right)$ and ECM fungal litter rate $(L)$. (d) ECM organic N uptake $\left(\mathrm{NORG}_{\mathrm{RATE}}\right)$ and $\mathrm{C} / \mathrm{N}$ of microbes $\left(\mathrm{CN}_{\mathrm{MIC}}\right)$.

ble A1d). These two approaches thus show large differences in simulating litter production. The discrepancy could also be due to (2) an enhanced $\mathrm{N}$ immobilization in ECM under $\mathrm{N}$ limited conditions based on the assumption that ECM retain more $\mathrm{N}$ in their own biomass in response to plant allocation of newly assimilated C (Nehls et al., 2008). The increasing trend towards the northern sites shown by the constrained optimum ECM C allocation fraction parameter (Fig. 8) also indicates a higher proportional $\mathrm{C}$ investment by the forest plants in ECM in northern, N-limited conditions. The resulting ECM-plant competition for $\mathrm{N}$ could then potentially result in decreased plant $\mathrm{N}$ uptake and thus plant growth (Näsholm et al., 2013). Finally, the discrepancy could be due to (3) biases in simulating ECM N uptake due to model or parameter uncertainties caused by high variability among ECM species and the scarcity of direct measurements in the field (Smith and Read, 2008; Clemmensen et al., 2013). The current explicit approach implements many biotic interactions and internal feedbacks within the plant-soil-ECM continuum. However, increasing the number of processes and interactions in an already complex ecosystem model will not nec- essarily generate more reliable model predictions; as shown here, the parameters in the explicit approach have a larger uncertainty range and show high correlations with other parameters even after calibration. This is also shown by the smaller accepted ratio in the calibration (Table 4), which can be explained by model complexity, i.e., as more parameters are included for calibration, accepted combinations of parameter sets become less likely.

It should also be noted that the explicit and implicit approaches show considerable difference in estimating soil respiration. Compared to the implicit approach, the explicit approach simulates a $15 \%$ higher soil respiration for the northernmost site and $40 \%$ for the southernmost site. The measured soil respiration at Flakaliden is 400 to $590 \mathrm{~g} \mathrm{C} \mathrm{m}^{-2} \mathrm{yr}^{-1}$ (Coucheney et al., 2013) and 460 to $520 \mathrm{~g} \mathrm{C} \mathrm{m}^{-2} \mathrm{yr}^{-1}$ at Asa (Von Arnold et al., 2005) and these data generally align better with the results modeled by the explicit approach (Fig. 5). The estimated higher soil respiration is partly due to the higher litter production and consequently soil respiration in the explicit approach but also due to a higher decomposition of the old organic matter (humus) 
as shown by the constrained higher humus decomposition coefficient, $K_{\mathrm{H}}$, in the explicit approach (Fig. 7). This corresponds well with findings from field measurements and recent modeling studies that ECM are able to degrade complex $\mathrm{N}$ polymers in humus layers, thus enhancing soil $\mathrm{N}$ transformation under low-N conditions (Hartley et al., 2012; Moore et al., 2015; Lindahl and Tunlid, 2015; Parker et al., 2015; Baskaran et al., 2016). The modeled higher soil respiration further explains the minor losses of soil $\mathrm{C}$ and $\mathrm{N}$ at the southern sites and also a higher mineral $\mathrm{N}$ pool and thus higher $\mathrm{N}$ leaching in the explicit approach (Figs. 3 and 4).

\subsection{Constrained parameters}

Our constrained parameters generally indicate a shift in the role of ECM from northern to southern sites with a corresponding shift in both climate and soil conditions (Figs. 6, 7, and 8). The ECM $\mathrm{N}$ uptake parameters show a decreasing trend with increasing soil $\mathrm{N}$ availability in the explicit approach. This is consistent with observations that at the northern $\mathrm{N}$-limited sites, organic $\mathrm{N}$ uptake by ECM is highly important for plant growth, becoming less important as $\mathrm{N}$ availability increases southwards (e.g., Hyvönen et al., 2008; Näsholm et al., 2013). Shown by the explicit approach, the mycorrhization degree of tree roots at Lycksele and Mora (>90\%) is much higher than that of Ljungbyhed (15\%); thus the majority of modeled $\mathrm{N}$ uptake is through fungal mycelia at northern sites. A similar trend is also found for the organic $\mathrm{N}$ uptake parameter in the implicit approach, but with a larger site-to-site difference, thus indicating a stronger response to soil $\mathrm{N}$ conditions (Fig. 6). This is expected as more detailed ECM processes in the explicit approach should result in more internal interactions and feedbacks and thus more resilience to the change of environmental conditions.

Most ECM fungal parameters in the explicit approach are not - or only weakly - dependent on the differing environmental conditions along the modeled transect, except for the $\mathrm{N}$ uptake parameters (NORG $\mathrm{RATE}_{\text {) }}$ and ECM fungal minimum $\mathrm{C} / \mathrm{N}$ ratio $\left(\mathrm{CN}_{\mathrm{FMIN}}\right)$, which show different mean values (Fig. 8). As such, these parameters need to be calibrated carefully when further applying the model to other sites with different soil nutrient levels or climate conditions.

Most of our constrained parameter distributions are not sharply peaked, but instead rather flat, and few parameters show high covariance (Figs. 6-9). This is, however, not a unique characteristic of the CoupModel or currently used data constraints and, indeed, has been previously demonstrated in numerous studies with ecosystem models of similar complexity (e.g., He et al., 2016; Klemedtsson et al., 2008; Wang et al., 2001). On the one hand, this generally reflects the equifinality of models (Beven, 2006), where multiple parameter sets can lead to equally good representations of the system. One the other hand, it also indicates poor identifiability of the calibrated parameters with respect to the available information for parameterization. Here, we again show that given the same data constraints, the parameter identifiability decreases with increasing model complexity (Sierra et al., 2015). In our study, the correlation between the humus decomposition coefficient, $K_{\mathrm{H}}$, and the fraction of $\mathrm{C}$ that is allocated to the rooting zone, $F_{\mathrm{ROOT}}$, is smaller when ECM are modeled explicitly rather than implicitly (Fig. 9). However, the correlations between the ECM fungal litter rate and ECM fungal $\mathrm{N}$ uptake rates, and that between fungal $\mathrm{N}$ uptake rates $\left(\mathrm{NORG}_{\mathrm{RATE}}\right)$ and the microbial $\mathrm{C} / \mathrm{N}$ ratio $\left(\mathrm{CN}_{\mathrm{MIC}}\right)$ (Fig. 9) further indicate these ECM fungal parameters in the more complex explicit model cannot be identified well without adding a new dataset as additional constraint. One of the major challenges of explicitly including ECM in ecosystem models is the still sparse information about ECM, e.g., unknown turnover of ECM mycelia (Ekblad et al., 2013). Previously reported turnover rates of newly formed mycelia vary from days to weeks, even up to 10 years (Staddon et al., 2003; Wallander et al., 2004), mostly due to the high variability in ECM species and structures (see review by Ekblad et al., 2013). Additionally, root turnover rates can also vary considerably between species, soils, and climate zones (Brunner et al., 2012). Thus far, very few studies have reported parameterization of $\mathrm{C}$ and $\mathrm{N}$ cycling for ECM in boreal forests. The present model calibration thus provides a key set of ECM parameters that can be further tested by field observations, and more importantly, can act as a prior for future ECM modeling studies.

\section{Conclusions}

The key components and features of the Coup-MYCOFON model have been described. The new version of CoupModel explicitly accounts for the links and feedback among ECM, soil, and plant. The comparison of three modeling approaches that differ in complexity demonstrates that the simple nonlim approach cannot describe the soil C / N ratio and also overestimates forest growth. When including ECM either implicitly or explicitly, both models deliver accurate long-term quantitative predictions on forest $\mathrm{C}$ and $\mathrm{N}$ cycling with simultaneous considerations of the impact of ECM on ecosystem dynamics. However, the implicit approach shows a much lower litter production and soil respiration than the explicit approach, and both approaches slightly underestimate forest growth. The ECM explicit Coup-MYCOFON model provides a more detailed description of internal ecosystem flux and feedback of $\mathrm{C}$ and $\mathrm{N}$. The constrained ECM parameter distributions presented in this study can be used as guidelines for future model applications. Overall, our model implementation and comparison suggest that ecosystem models need to incorporate ECM into their model structure for a better prediction of ecosystem C and $\mathrm{N}$ dynamics. 
Code availability. The model and extensive documentation with tutorial excises are freely available from the CoupModel home page http://www.coupmodel.com/ (CoupModel, 2015). The source code will be available to download from the home page and a link to a repository for MS Visual studio can also be provided. CoupModel is written in the $\mathrm{C}$ programming language and runs mainly under Windows systems. The version used as the basis for the present development was version 5 from 12 April 2017. The simulation files including the model and calibration setup, the parameterization used, and corresponding input and validation files can be requested from Hongxing He (hongxing.he@gu.se). 


\section{Appendix A}

Table A1. Model functions describing plant growth, ECM fungal growth, model parameters, and response functions of plant and ECM. Parameters are always shown with capital letters. (a) Description of plant model functions. ( $i$ is fine roots, coarse roots, stem, leaves, grain, mobile). (b) Functions describing processes related to ECM fungal growth and $\mathrm{N}$ exchange to plant. (c) Overview of response functions of plant and ECM fungal growth and $\mathrm{N}$ uptake. (d) Overview of model parameters; previous CoupModel parameters are mostly from Svensson et al. (2008a) and ECM parameters are from literature values (Meyer et al., 2012, and references therein).

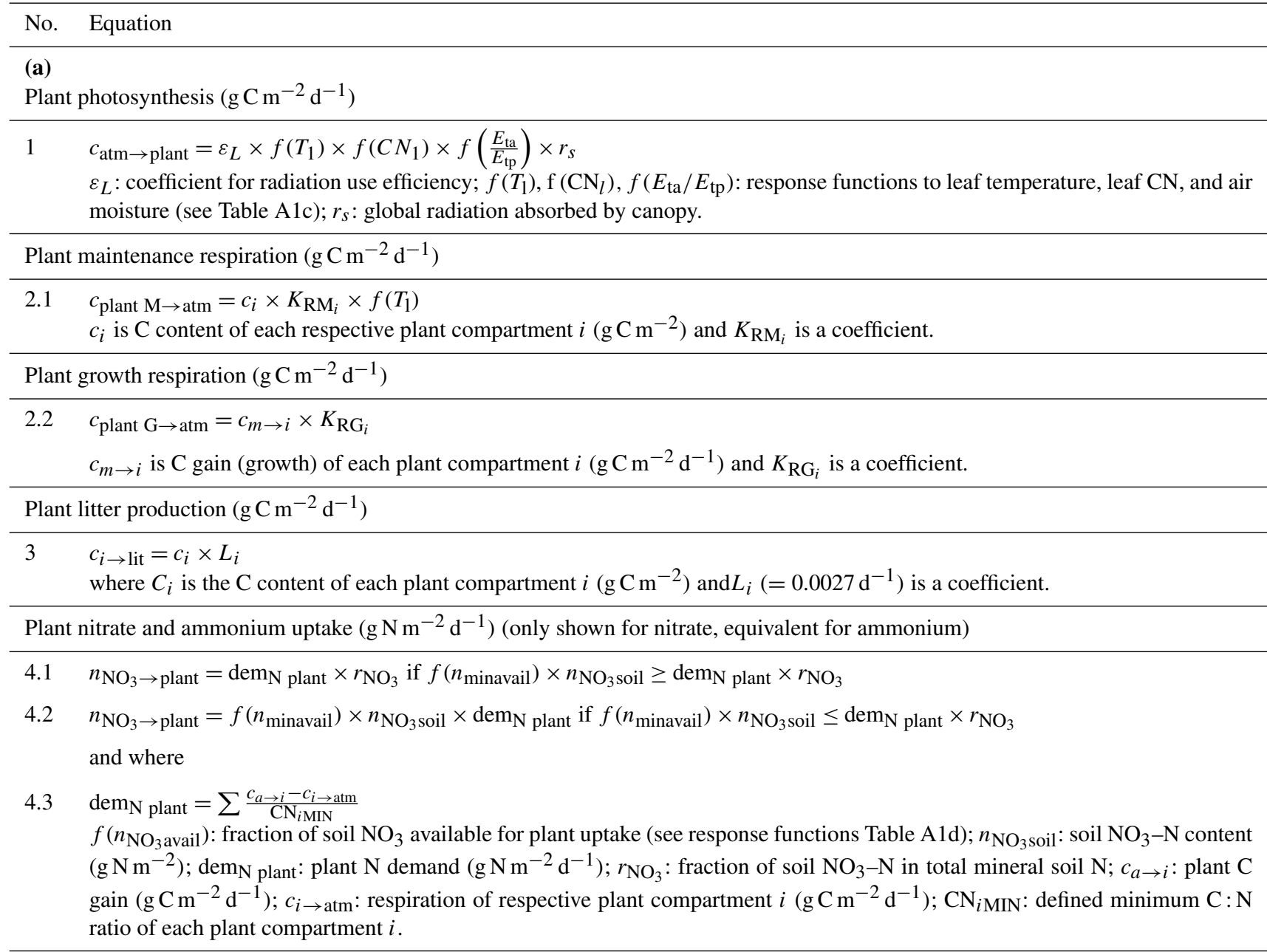

Plant organic $\mathrm{N}$ uptake $\left(\mathrm{g} \mathrm{N} \mathrm{m}^{-2} \mathrm{~d}^{-1}\right)$ from the humus layer

$4.4 \quad n_{\text {hum } \rightarrow \text { plant }}=$ dem $_{\mathrm{N} \text { plant }} \times r_{\text {hum }}$ if $f\left(n_{\text {humavail }}\right) \times n_{\text {humsoil }} \geq \operatorname{dem}_{\mathrm{N} \text { plant }} \times r_{\text {hum }}$

4.5 $\quad n_{\text {hum } \rightarrow \text { plant }}=f\left(n_{\text {humavail }}\right) \times n_{\text {humsoil }}$ if $f\left(n_{\text {humavail }}\right) \times n_{\text {humsoil }}<\operatorname{dem}_{\mathrm{N} \text { plant }} \times r_{\text {hum }}$

$f\left(n_{\text {humavail }}\right)$ : response function for plant-available $\mathrm{N}$ from the humus layer; $n_{\text {humsoil }}$ : soil $\mathrm{N}$ content in humus layer $\left(\mathrm{g} \mathrm{N} \mathrm{m}^{-2}\right)$.

(b)

ECM fungal maximum $\mathrm{C}$ supply $\left(\mathrm{g} \mathrm{C} \mathrm{m}^{-2} \mathrm{~d}^{-1}\right)$

$5.1 \quad c_{\mathrm{a} \rightarrow \text { fungi }}=c_{\mathrm{a} \rightarrow \text { root }} \times \mathrm{FRAC}_{\mathrm{FMAX}} \times f\left(c_{\text {fungiavail }}\right)$ 
Table A1. Continued.

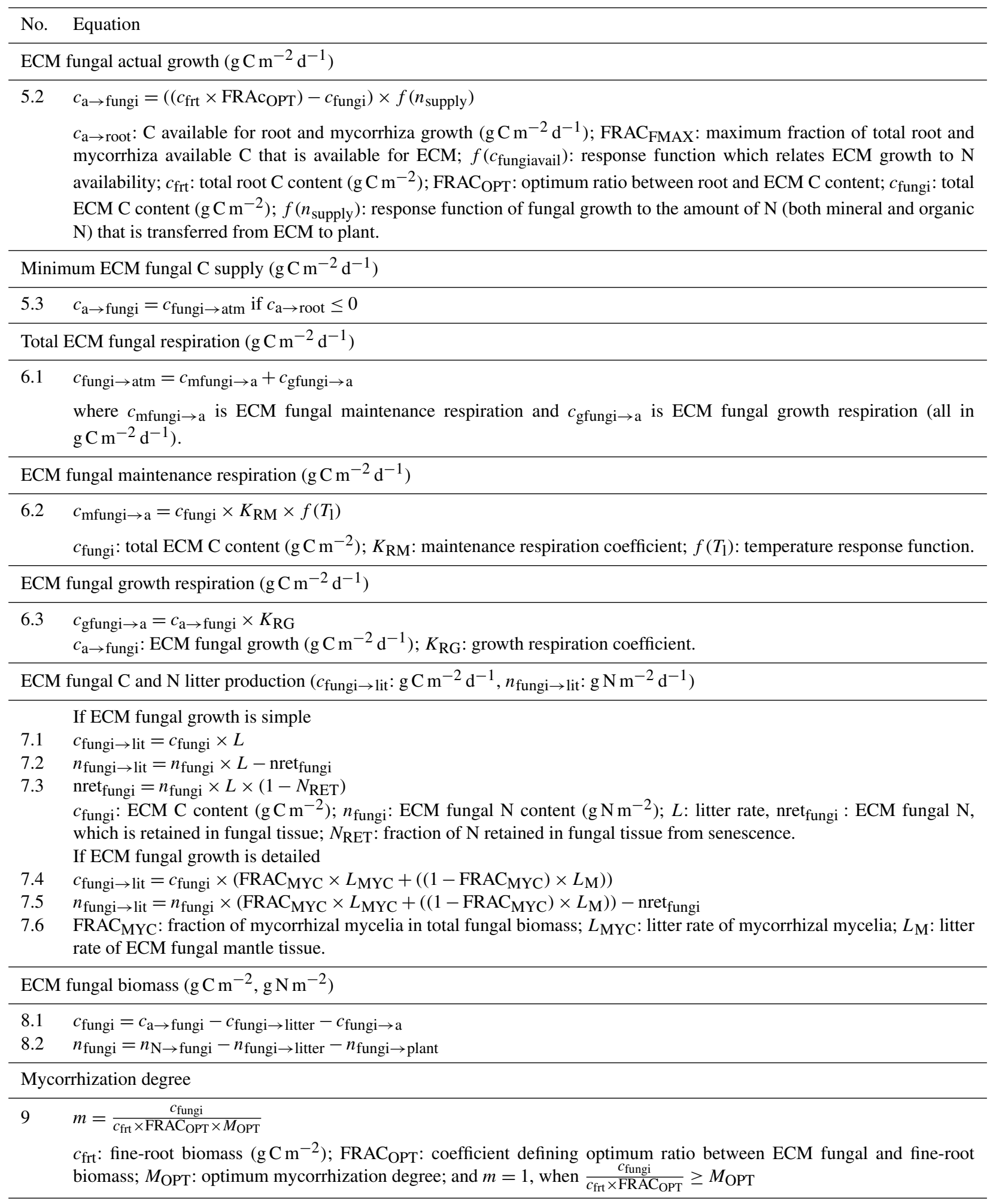


Table A1. Continued.

\begin{tabular}{|c|c|}
\hline No. & Equation \\
\hline \multicolumn{2}{|c|}{ Uptake and transfer processes of ECM and plant } \\
\hline \multicolumn{2}{|c|}{$\mathrm{N}$ transfer from ECM to plant $\left(\mathrm{g} \mathrm{N} \mathrm{m}^{-2} \mathrm{~d}^{-1}\right)$} \\
\hline 10.2 & 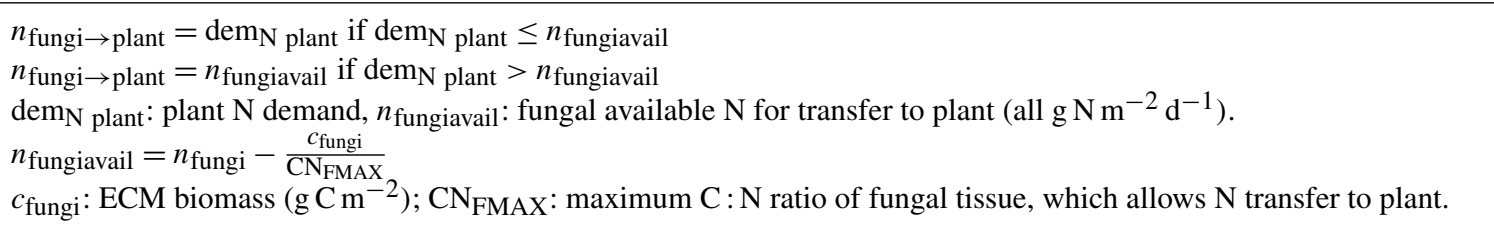 \\
\hline \multicolumn{2}{|r|}{ ECM fungal nitrate and ammonium uptake (given for nitrate, equivalent for ammonium with ammonium-specific parameter) } \\
\hline $\begin{array}{l}11.1 \\
11.2 \\
11.3\end{array}$ & 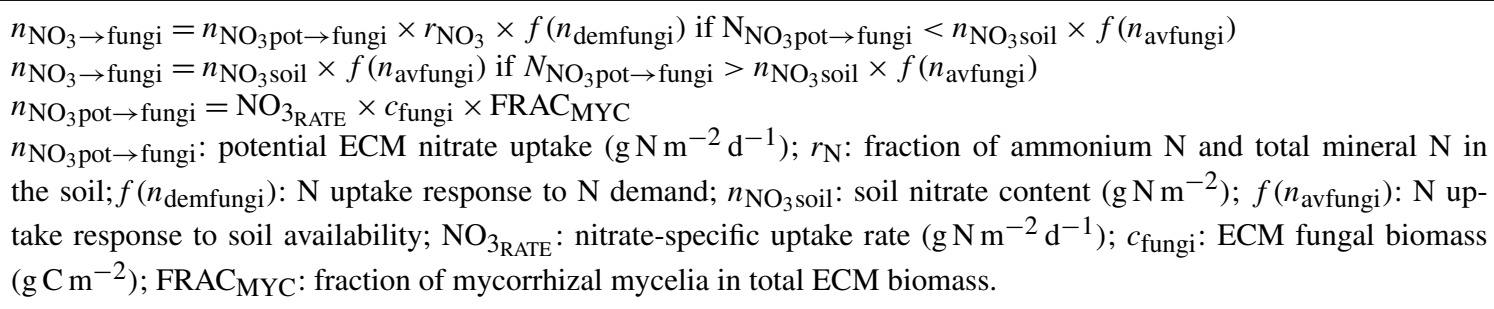 \\
\hline \multicolumn{2}{|r|}{ ECM fungal organic $\mathrm{N}$ uptake from litter and humus (given for litter, equivalent for humus with humus-specific parameter) } \\
\hline $\begin{array}{l}11.4 \\
11.5 \\
11.6\end{array}$ & $\begin{array}{l}n_{\text {lit } \rightarrow \text { fungi }}=n_{\text {litpot } \rightarrow \text { fungi }} \times r_{\text {lit }} \times f\left(n_{\text {demfungi }}\right) \text { if } n_{\text {litpot } \rightarrow \text { fungi }} \times r_{\text {lit }}<n_{\text {litsoil }} \times f\left(n_{\text {litavfungi }}\right) \times r_{\text {lit }} \\
n_{\text {lit } \rightarrow \text { fungi }}=n_{\text {litsoil }} \times f\left(n_{\text {litavfungi }}\right) \times r_{\text {lit }} \text { if } n_{\text {litpot } \rightarrow \text { fungi }} \times r_{\text {lit }}>n_{\text {litsoil }} \times f\left(n_{\text {litavfungi }}\right) \times r_{\text {lit }} \\
n_{\text {litpot } \rightarrow \text { fungi }}=\mathrm{LIT}_{\text {RATE }} \times c_{\text {fungi }} \times \text { FRAC } \\
\text { where } n_{\text {litpot } \rightarrow \text { fungi }} \text { is potential ECM organic } \mathrm{N} \text { uptake from litter }\left(\mathrm{g} \mathrm{N} \mathrm{m}^{-2} \mathrm{~d}^{-1}\right), r_{\text {lit }} \text { is fraction of litter N in total } \\
\text { organic } \mathrm{N} \text { in the soil, } f\left(n_{\text {demfungi }}\right) \text { is N uptake response to } \mathrm{N} \text { demand, } n_{\text {litsoil }} \text { is soil litter content }\left(\mathrm{g} \mathrm{N} \mathrm{m}^{-2}\right), \mathrm{NLIT}_{\mathrm{RATE}} \\
\text { is litter-specific uptake rate }\left(\mathrm{g} \mathrm{N} \mathrm{C}^{-1} \mathrm{~d}^{-1}\right), c_{\text {fungi }} \text { is ECM fungal biomass }\left(\mathrm{g} \mathrm{C} \mathrm{m}^{-2}\right) \text {, and FRAC } \mathrm{MYC}_{\text {is fraction of }} \\
\text { mycorrhizal mycelia in total ECM biomass. }\end{array}$ \\
\hline
\end{tabular}

(c)

Plant response to air temperature

\begin{tabular}{|c|c|c|c|}
\hline 12 & $f\left(T_{1}\right)=$ & $\begin{array}{l}0 \\
\left(T_{1}-p_{\min }\right) /\left(p_{\mathrm{O}_{1}}-p_{\min }\right) \\
1 \\
1-\left(T_{1}-p_{\mathrm{O}_{2}}\right) /\left(p_{\max }-P_{\mathrm{O}_{2}}\right) \\
0\end{array}$ & $\begin{array}{l}T_{1}<P_{\min } \\
p_{\min } \leq T_{1} \leq p_{\mathrm{O}_{1}} \\
p_{\mathrm{O}_{1}}<T_{1}<p_{\mathrm{O}_{2}} \\
p_{\mathrm{O}_{2}}<T_{1}<p_{\max } \\
T_{1}>p_{\max }\end{array}$ \\
\hline
\end{tabular}

Photosynthetic response to leaf $\mathrm{C} / \mathrm{N}$ ratio

$\left.13 \quad f\left(\mathrm{CN}_{l}\right)=\begin{array}{ll}1 & \mathrm{CN}_{l}<p_{\mathrm{CNOPT}} \\ 0 & p_{\mathrm{CNTH}} \leq \mathrm{CN}_{1} \geq p_{\mathrm{CNOPT}}-p_{\mathrm{CNOPT}} \\ p_{\mathrm{COPT}}-p_{\mathrm{CNTH}}\end{array}\right) \quad \begin{aligned} & \mathrm{CN}_{1}>p_{\mathrm{CNTH}}\end{aligned}$

where $\mathrm{CN}_{1}$ is leaf $\mathrm{C} / \mathrm{N}$ ratio and $p_{\mathrm{CNOPT}}(25)$ and $p_{\mathrm{CNTH}}(75)$ are parameters.

Plant response to soil moisture

$14 f\left(\frac{E_{\mathrm{ta}}}{E_{\mathrm{tp}}}\right)=\frac{E_{\mathrm{ta}}}{E_{\mathrm{tp}}}$

where $E_{\mathrm{ta}}$ is actual transpiration and $E_{\mathrm{tp}}$ is potential transpiration $\left(\mathrm{mm} \mathrm{d}^{-1}\right)$. 
Table A1. Continued.

\begin{tabular}{|c|c|}
\hline No. & Equation \\
\hline \multicolumn{2}{|r|}{ Plant mineral $\mathrm{N}$ uptake response to $\mathrm{N}$ availability and $\mathrm{ECM}$ fungal mantle } \\
\hline 15 & $\begin{array}{l}f\left(n_{\text {minavail }}\right)=\text { NUPT }_{\text {FRACMAX }} \times e^{(-\mathrm{FM} \times m)} \\
\text { where NUPT } \\
\text { ECACMAX fungal mantle. }\end{array}$ \\
\hline \multicolumn{2}{|r|}{ Plant organic $\mathrm{N}$ uptake response to $\mathrm{N}$ availability and $\mathrm{ECM}$ fungal mantle (given for litter, equivalent for humus) } \\
\hline 16 & $\begin{array}{l}f\left(n_{\text {litavail }}\right)=\text { NUPT }_{\text {ORGFRACMAX }} \times e^{(-\mathrm{FM} \times m)} \\
\text { where NUPT } \\
\text { uptake reduction due to ECM fungal mantle. }\end{array}$ \\
\hline \multicolumn{2}{|c|}{ ECM N uptake response to $\mathrm{N}$ availability } \\
\hline 17.1 & $f\left(n_{\text {avfungi }}\right)=\mathrm{NUPT}_{\mathrm{FRACMAX}} \times \mathrm{UPT}_{\text {MINENHANCE }}$ for nitrate \\
\hline 17.2 & $f\left(n_{\text {avfungi }}\right)=\mathrm{NUPT}_{\mathrm{FRACMAX}} \times \mathrm{UPT}_{\mathrm{MINERAL}} \times \mathrm{UPT}_{\mathrm{NH}_{4}}$ for ammonium \\
\hline 17.3 & $f\left(n_{\text {orgavfungi }}\right)=$ NUPT $_{\text {ORGFRACMACX }} \times \mathrm{UPT}_{\text {ORG }}$ for litter/humus \\
\hline \multicolumn{2}{|c|}{ ECM N uptake response to $\mathrm{N}$ demand } \\
\hline 18 & $\begin{array}{l}f\left(n_{\text {demfungi }}\right)=1-\frac{\mathrm{CN}_{\mathrm{FMIN}}}{\mathrm{CN}_{\text {fungi }}} \\
\text { where } \mathrm{CN}_{\mathrm{FMIN}} \text { is the minimum ECM C / N ratio. }\end{array}$ \\
\hline 19 & $\begin{array}{l}f\left(c_{\text {fungiavail }}\right)=e\left(-\mathrm{N}_{\mathrm{AVAIL}} \mathrm{COEF}_{\text {minsoil }}\right)^{3} \\
\text { where NAVAIL } \mathrm{COEF} \text { is a coefficient and } \mathrm{N}_{\text {minsoil }} \text { is the total soil content of ammonium and nitrate }\left(\mathrm{g} \mathrm{N} \mathrm{m}^{-2}\right) \text {. }\end{array}$ \\
\hline 20.1 & $f\left(n_{\text {supplyfungi })}=1\right.$ if $\min _{\mathrm{N}}$ Plant $<n_{\text {fungi } \rightarrow \text { plant }}$ \\
\hline 20.2 & 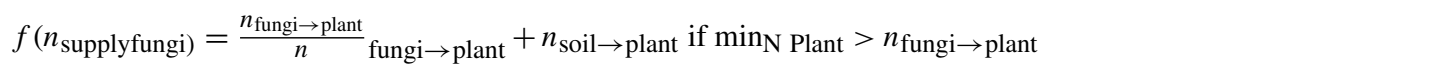 \\
\hline 20.3 & $\begin{array}{l}\min _{\mathrm{N} \text { Plant }}=\mathrm{MIN}_{\mathrm{SUPL}} \cdot\left(n_{\mathrm{fungi} \rightarrow \text { plant }}+n_{\mathrm{Soil} \rightarrow \text { plant }}\right) \\
\text { where } \min _{\mathrm{N} \text { Plant }} \text { is the defined minimum ECM fungal } \mathrm{N} \text { supply in plant } \mathrm{N} \text { uptake, } n_{\text {fungi } \rightarrow \text { plant }} \text { is actual ECM } \\
\mathrm{N} \text { supply to plant }\left(\mathrm{g} \mathrm{N} \mathrm{m}^{-2} \mathrm{~d}^{-1}\right) \text {, and } n_{\text {soil } \rightarrow \text { plant }} \text { is total plant } \mathrm{N} \text { uptake from the mineral and organic fraction } \\
\left(\mathrm{g} \mathrm{N} \mathrm{m}^{-2} \mathrm{~d}^{-1}\right) \text {. }\end{array}$ \\
\hline
\end{tabular}

\begin{tabular}{|c|c|c|c|}
\hline $\begin{array}{l}\text { (d) } \\
\text { Parameter }\end{array}$ & Description & Value & Unit \\
\hline $\mathrm{CN}_{\mathrm{FMIN}}$ & Minimum ECM C / N ratio for fungal $\mathrm{N}$ demand & 18 & $\mathrm{gCg} \mathrm{N}^{-1}$ \\
\hline $\mathrm{CN}_{\mathrm{FMAX}}$ & Maximum ECM C / $\mathrm{N}$ ratio for $\mathrm{N}$ transfer to plant & 30 & $\mathrm{gCg} \mathrm{N}^{-1}$ \\
\hline \multirow[t]{3}{*}{$\mathrm{CN}_{i \mathrm{MIN}}$} & Minimum C / N ratio of fine roots & 40 & $\mathrm{gCg} \mathrm{N}^{-1}$ \\
\hline & Needles/leaves & 22 & $\mathrm{gCg} \mathrm{N}^{-1}$ \\
\hline & Coarse roots and stem & 450 & $\mathrm{gCg} \mathrm{N}^{-1}$ \\
\hline$E_{L}$ & Coefficient for radiation use efficiency & 8 & \\
\hline$E_{\mathrm{NH}_{4}}$ & $\mathrm{ECM} \mathrm{NH}_{4}$ uptake enhancement factor & 5 & \\
\hline $\mathrm{FM}$ & Plant $\mathrm{N}$ uptake reduction due to ECM mantle & 0.5 & \\
\hline FRAC $_{\text {FMAX }}$ & $\begin{array}{l}\text { Maximum fraction of } \mathrm{C} \text { allocated to rooting } \\
\text { zone which is made available for ECM }\end{array}$ & 0.5 & \\
\hline FRAC $_{\text {MYC }}$ & Fraction of ECM mycelia in total biomass & 0.5 & \\
\hline FRAC $_{\mathrm{OPT}}$ & Optimum fraction between root and ECM biomass & 0.3 & \\
\hline$K_{\mathrm{RGF}}$ & Growth respiration coefficient of ECM & 0.21 & $d^{-1}$ \\
\hline$K_{\mathrm{RM}_{i}}$ & $\begin{array}{l}\text { Maintenance respiration coefficient of plant } \\
\text { compartment } i \text { ( } i \text { is fine roots, coarse roots, stem, leaves) }\end{array}$ & 0.001 & $\mathrm{~d}^{-1}$ \\
\hline$K_{\mathrm{RG}_{i}}$ & $\begin{array}{l}\text { Growth respiration coefficient of } \\
\text { plant compartment } i\end{array}$ & 0.21 & $\mathrm{~d}^{-1}$ \\
\hline
\end{tabular}


Table A1. Continued.

\begin{tabular}{llrc}
\hline Parameter & Description & Value & Unit \\
\hline$L_{\text {FRT }}$ & Litter rate of fine roots & 0.0027 & $\mathrm{~d}^{-1}$ \\
$L_{\mathrm{CRT}}$ & Litter rate of coarse roots & 0.000027 & $\mathrm{~d}^{-1}$ \\
$L_{\mathrm{LEAF}}$ & Litter rate of needles & 0.0002 & $\mathrm{~d}^{-1}$ \\
$L_{\mathrm{STEM}}$ & Litter rate of stem & 0.000027 & $\mathrm{~d}^{-1}$ \\
$L$ & Litter rate of ECM (if fungal growth is simple) & 0.004 & \\
$L_{\mathrm{M}}$ & Litter rate of ECM mantle (if fungal growth is detailed) & 0.0014 & $\mathrm{~d}^{-1}$ \\
$L_{\mathrm{MYC}}$ & Litter rate of ECM mycelia & 0.01 & $\mathrm{~d}^{-1}$ \\
& (if fungal growth is detailed) & & \\
$M_{\text {OPT }}$ & Optimum mycorrhization degree of fine roots $<2 \mathrm{~mm}$ & 0.5 & \\
$N_{\text {RET }}$ & N retained by ECM from senescence & 0.54 & $\mathrm{~d}^{-1}$ \\
NUPT & fraction of mineral N available for uptake & 0.08 & $\mathrm{~d}^{-1}$ \\
\hline
\end{tabular}

Table A2. Correlation between common model parameters for all simulated sites with the implicit and explicit approaches. Correlation is given as the Pearson correlation coefficient.

\begin{tabular}{|c|c|c|c|c|c|c|c|c|c|}
\hline & & \multicolumn{4}{|c|}{ Implicit } & \multicolumn{4}{|c|}{ Explicit } \\
\hline & & $K_{\mathrm{H}}$ & $\mathrm{NUPT}_{\mathrm{OFM}}$ & $F_{\text {ROOT }}$ & $\mathrm{CN}_{\mathrm{MIC}}$ & $K_{\mathrm{H}}$ & $\mathrm{NUPT}_{\mathrm{OFM}}$ & $F_{\text {ROOT }}$ & $\mathrm{CN}_{\mathrm{MIC}}$ \\
\hline \multirow{4}{*}{ 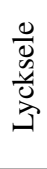 } & $K_{\mathrm{H}}$ & 1 & -0.20 & 0.67 & 0.23 & 1 & -0.08 & 0.28 & 0.21 \\
\hline & NUPT $_{\text {OFM }}$ & & 1 & 0.24 & -0.57 & & 1 & 0.02 & -0.35 \\
\hline & $F_{\text {ROOT }}$ & & & 1 & 0.18 & & & 1 & 0.02 \\
\hline & $\mathrm{CN}_{\mathrm{MIC}}$ & & & & 1 & & & & 1 \\
\hline \multirow{4}{*}{$\stackrel{\pi}{\tilde{a}}$} & $K_{\mathrm{H}}$ & 1 & -0.13 & 0.73 & 0.11 & 1 & 0.08 & 0.22 & 0.04 \\
\hline & NUPT $_{\text {OFM }}$ & & 1 & 0.18 & -0.64 & & 1 & 0.10 & -0.46 \\
\hline & $F_{\text {ROOT }}$ & & & 1 & 0.13 & & & 1 & 0.12 \\
\hline & $\mathrm{CN}_{\mathrm{MIC}}$ & & & & 1 & & & & 1 \\
\hline \multirow{4}{*}{ 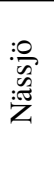 } & $K_{\mathrm{H}}$ & 1 & 0.03 & 0.70 & -0.08 & 1 & 0.13 & 0.29 & 0.16 \\
\hline & NUPT $_{\text {OFM }}$ & & 1 & 0.31 & -0.60 & & 1 & 0.29 & -0.53 \\
\hline & $F_{\mathrm{ROOT}}$ & & & 1 & 0.02 & & & 1 & 0.12 \\
\hline & $\mathrm{CN}_{\mathrm{MIC}}$ & & & & 1 & & & & 1 \\
\hline \multirow{4}{*}{ 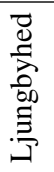 } & $K_{\mathrm{H}}$ & 1 & 0.03 & 0.66 & -0.18 & 1 & 0.33 & 0.26 & -0.19 \\
\hline & NUPT $_{\text {OFM }}$ & & 1 & 0.17 & -0.28 & & 1 & 0.23 & -0.26 \\
\hline & $F_{\text {ROOT }}$ & & & 1 & 0.24 & & & 1 & 0.07 \\
\hline & $\mathrm{CN}_{\mathrm{MIC}}$ & & & & 1 & & & & 1 \\
\hline
\end{tabular}


Table A3. Correlation between fungal and common model parameters with the explicit approach for all sites. Correlation is given as the Pearson correlation coefficient.

\begin{tabular}{|c|c|c|c|c|c|c|c|c|c|c|c|}
\hline & & Norg $_{\text {RATE }}$ & $\mathrm{NH}_{4_{\text {RATE }}}$ & $\mathrm{NO}_{3_{\text {RATE }}}$ & $K_{\mathrm{RM}}$ & $L_{\mathrm{MYC}}$ & $L_{\mathrm{M}}$ & $\mathrm{CN}_{\mathrm{FMIN}}$ & MIN $_{\text {SUPL }}$ & FRAC $_{\mathrm{OPT}}$ & NAVAIL $_{\mathrm{COEF}}$ \\
\hline \multirow{4}{*}{ 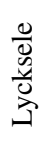 } & $K_{\mathrm{H}}$ & 0.17 & 0.16 & 0.16 & 0.01 & -0.30 & -0.27 & 0.02 & 0.00 & -0.17 & -0.13 \\
\hline & $\mathrm{NUPT}_{\mathrm{OFM}}$ & -0.32 & -0.28 & -0.28 & 0.09 & 0.13 & 0.13 & 0.18 & 0.10 & 0.01 & 0.02 \\
\hline & $F_{\text {ROOT }}$ & 0.06 & 0.03 & 0.03 & -0.05 & 0.03 & 0.03 & 0.00 & 0.06 & -0.04 & -0.15 \\
\hline & $\mathrm{CN}_{\mathrm{MIC}}$ & -0.33 & -0.34 & -0.34 & 0.00 & 0.21 & 0.21 & 0.23 & 0.03 & -0.12 & -0.01 \\
\hline \multirow{4}{*}{$\frac{\widetilde{\pi}}{2}$} & $K_{\mathrm{H}}$ & 0.22 & 0.20 & 0.20 & -0.09 & -0.25 & -0.21 & -0.02 & 0.08 & -0.14 & -0.04 \\
\hline & $\mathrm{NUPT}_{\mathrm{OFM}}$ & -0.15 & -0.09 & -0.09 & 0.08 & 0.02 & 0.02 & 0.05 & 0.11 & -0.08 & 0.00 \\
\hline & $F_{\text {ROOT }}$ & -0.11 & -0.12 & -0.12 & 0.06 & 0.26 & 0.26 & 0.25 & -0.06 & -0.01 & 0.01 \\
\hline & $\mathrm{CN}_{\mathrm{MIC}}$ & -0.38 & -0.40 & -0.40 & -0.03 & 0.29 & 0.29 & 0.33 & -0.10 & -0.08 & -0.08 \\
\hline \multirow{4}{*}{ 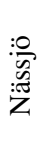 } & $K_{\mathrm{H}}$ & 0.20 & 0.18 & 0.18 & -0.06 & -0.33 & -0.32 & -0.13 & 0.08 & -0.03 & -0.08 \\
\hline & NUPT $_{\text {OFM }}$ & -0.07 & -0.03 & -0.03 & -0.05 & -0.11 & -0.11 & -0.12 & -0.03 & 0.18 & -0.06 \\
\hline & $F_{\text {ROOT }}$ & -0.06 & -0.03 & -0.03 & 0.01 & 0.08 & 0.08 & 0.09 & -0.08 & 0.14 & -0.08 \\
\hline & $\mathrm{CN}_{\mathrm{MIC}}$ & -0.23 & -0.20 & -0.20 & 0.05 & 0.11 & 0.11 & 0.15 & -0.02 & -0.17 & 0.09 \\
\hline \multirow{4}{*}{ 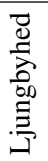 } & $K_{\mathrm{H}}$ & 0.34 & 0.36 & 0.36 & -0.08 & -0.51 & -0.53 & -0.13 & 0.18 & -0.22 & -0.20 \\
\hline & $\mathrm{NUPT}_{\mathrm{OFM}}$ & 0.10 & 0.16 & 0.16 & 0.05 & -0.21 & -0.21 & -0.24 & 0.06 & -0.13 & -0.07 \\
\hline & $F_{\text {ROOT }}$ & -0.11 & -0.07 & -0.07 & 0.19 & 0.10 & 0.10 & 0.11 & 0.04 & 0.02 & -0.02 \\
\hline & $\mathrm{CN}_{\mathrm{MIC}}$ & -0.22 & -0.21 & -0.21 & 0.01 & 0.15 & 0.15 & 0.18 & -0.05 & 0.02 & 0.07 \\
\hline
\end{tabular}


Table A4. Correlation between fungal model parameters with the explicit approach for all sites. Correlation is given as the Pearson correlation coefficient.

\begin{tabular}{|c|c|c|c|c|c|c|c|c|c|c|c|}
\hline & & Norg $_{\text {RATE }}$ & $\mathrm{NH}_{4_{\text {RATE }}}$ & $\mathrm{NO}_{3_{\text {RATE }}}$ & $K_{\mathrm{RM}}$ & $L_{\mathrm{MYC}}$ & $L_{\mathrm{M}}$ & $\mathrm{CN}_{\mathrm{FMIN}}$ & MIN $_{S U P L}$ & $\mathrm{FRAC}_{\mathrm{OPT}}$ & NAVAIL $_{\text {COEF }}$ \\
\hline \multirow{10}{*}{\begin{tabular}{l}
$\frac{0}{0}$ \\
$\frac{\tilde{D}}{0}$ \\
\multirow{3}{\Delta}{}
\end{tabular}} & Norg $_{\text {RATE }}$ & 1 & 0.91 & 0.91 & 0.01 & -0.55 & -0.59 & -0.10 & -0.07 & 0.07 & -0.03 \\
\hline & $\mathrm{NH}_{4_{\text {RATE }}}$ & & 1 & 0.99 & 0.01 & -0.50 & -0.56 & -0.07 & -0.05 & 0.07 & -0.03 \\
\hline & $\mathrm{NO}_{3_{\text {RATE }}}$ & & & 1 & 0.01 & -0.50 & -0.56 & -0.07 & -0.05 & 0.07 & -0.03 \\
\hline & $K_{\mathrm{RM}}$ & & & & 1 & -0.1 & -0.1 & -0.06 & -0.07 & -0.03 & -0.04 \\
\hline & $L_{\mathrm{MYC}}$ & & & & & 1 & 0.95 & 0.04 & 0.07 & -0.17 & -0.03 \\
\hline & $L_{\mathrm{M}}$ & & & & & & 1 & 0.04 & 0.07 & -0.13 & -0.02 \\
\hline & $\mathrm{CN}_{\mathrm{FMIN}}$ & & & & & & & 1 & 0.05 & 0.07 & 0.05 \\
\hline & MIN $_{S U P L}$ & & & & & & & & 1 & 0 & 0.05 \\
\hline & FRAC $_{\mathrm{OPT}}$ & & & & & & & & & 1 & 0.17 \\
\hline & NAVAIL $_{\text {COEF }}$ & & & & & & & & & & 1 \\
\hline \multirow{10}{*}{$\stackrel{\pi}{\stackrel{\pi}{2}}$} & Norg $_{\text {RATE }}$ & 1 & 0.88 & 0.88 & -0.09 & -0.40 & -0.48 & 0.02 & -0.05 & 0.04 & 0.06 \\
\hline & $\mathrm{NH}_{4_{\text {RATE }}}$ & & 1 & 0.99 & -0.08 & -0.32 & -0.43 & 0.01 & -0.03 & 0.09 & 0.08 \\
\hline & $\mathrm{NO}_{3_{\text {RATE }}}$ & & & 1 & -0.08 & -0.32 & -0.43 & 0.01 & -0.03 & 0.09 & 0.08 \\
\hline & $K_{\mathrm{RM}}$ & & & & 1 & -0.07 & -0.06 & 0.01 & -0.15 & 0.05 & 0.05 \\
\hline & $L_{\mathrm{MYC}}$ & & & & & 1 & 0.95 & -0.08 & 0.05 & -0.21 & -0.02 \\
\hline & $L_{\mathrm{M}}$ & & & & & & 1 & -0.07 & 0.07 & -0.19 & -0.03 \\
\hline & $\mathrm{CN}_{\mathrm{FMIN}}$ & & & & & & & 1 & -0.08 & -0.01 & 0.04 \\
\hline & MIN $_{\text {SUPL }}$ & & & & & & & & 1 & 0.06 & 0.13 \\
\hline & FRAC $_{\mathrm{OPT}}$ & & & & & & & & & 1 & 0.02 \\
\hline & NAVAIL $_{\text {COEF }}$ & & & & & & & & & & 1 \\
\hline \multirow{10}{*}{ 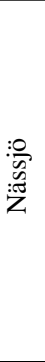 } & Norg $_{\text {RATE }}$ & 1 & 0.86 & 0.86 & 0.05 & -0.13 & -0.20 & -0.08 & -0.10 & 0.09 & -0.02 \\
\hline & $\mathrm{NH}_{4_{\text {RATE }}}$ & & 1 & 0.99 & 0.11 & 0.00 & -0.07 & -0.09 & -0.07 & 0.15 & -0.02 \\
\hline & $\mathrm{NO}_{3_{\text {RATE }}}$ & & & 1 & 0.11 & 0.00 & -0.07 & -0.09 & -0.07 & 0.15 & -0.02 \\
\hline & $K_{\mathrm{RM}}$ & & & & 1 & -0.05 & -0.06 & 0.01 & 0.05 & -0.01 & 0.01 \\
\hline & $L_{\mathrm{MYC}}$ & & & & & 1 & 0.96 & 0.07 & 0.06 & -0.11 & -0.02 \\
\hline & $L_{\mathrm{M}}$ & & & & & & 1 & 0.06 & 0.07 & -0.11 & -0.05 \\
\hline & $\mathrm{CN}_{\mathrm{FMIN}}$ & & & & & & & 1 & -0.07 & -0.07 & 0.08 \\
\hline & MIN $_{\text {SUPL }}$ & & & & & & & & 1 & -0.05 & -0.04 \\
\hline & FRAC $_{\mathrm{OPT}}$ & & & & & & & & & 1 & 0.02 \\
\hline & NAVAIL $_{\text {COEF }}$ & & & & & & & & & & 1 \\
\hline \multirow{10}{*}{ 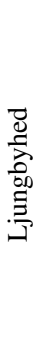 } & Norg $_{\text {RATE }}$ & 1 & 0.86 & 0.86 & -0.13 & -0.32 & -0.40 & -0.06 & 0.07 & 0.04 & -0.03 \\
\hline & $\mathrm{NH}_{4 \mathrm{RATE}}$ & & 1 & 0.99 & -0.07 & -0.21 & -0.28 & -0.05 & 0.02 & 0.06 & 0.00 \\
\hline & $\mathrm{NO}_{3}{ }_{\text {RATE }}$ & & & 1 & -0.07 & -0.21 & -0.28 & -0.05 & 0.02 & 0.06 & 0.00 \\
\hline & $K_{\mathrm{RM}}$ & & & & 1 & -0.09 & -0.08 & -0.01 & 0.01 & -0.03 & -0.05 \\
\hline & $L_{\mathrm{MYC}}$ & & & & & 1 & 0.96 & 0.01 & -0.08 & -0.04 & 0.12 \\
\hline & $L_{\mathrm{M}}$ & & & & & & 1 & 0.02 & -0.10 & -0.04 & 0.10 \\
\hline & $\mathrm{CN}_{\mathrm{FMIN}}$ & & & & & & & 1 & -0.03 & 0.16 & 0.04 \\
\hline & $\mathrm{MIN}_{\text {SUPL }}$ & & & & & & & & 1 & -0.07 & -0.03 \\
\hline & FRAC $_{\mathrm{OPT}}$ & & & & & & & & & 1 & 0.01 \\
\hline & NAVAIL $_{\text {COEF }}$ & & & & & & & & & & 1 \\
\hline
\end{tabular}


Competing interests. The authors declare that they have no conflict of interest.

Acknowledgements. We thank Annemieke Reurslag Gärdenäs for external review for this paper. Financial support came from the Swedish Research Council for Environment, Agricultural Sciences and Spatial Planning (FORMAS), the strategic research area BECC (Biodiversity and Ecosystem services in a Changing Climate, www.cec.lu.se/research/becc), and the Linnaeus Centre LUCCI (Lund University Centre for Studies of Carbon Cycle and Climate Interaction).

Edited by: Carlos Sierra

Reviewed by: Lyla L. Taylor and one anonymous referee

\section{References}

Bååth, E.: The use of neutral lipid fatty acids to indicate the physiological conditions of soil fungi, Microb. Ecol., 45, 373-383, 2003.

Bååth, E. and Söderström, B.: Fungal biomass and fungal immobilization of plant nutrients in Swedish forest soils, Rev. Ecol. Sol., 16, 477-489, 1979.

Bahr, A., Ellstrom, M., Akselsson, C., Ekblad, A., Mikusinska, A., and Wallander, H.: Growth of ectomycorrhizal fungal mycelium along a Norway spruce forest nitrogen deposition gradient and its effect on nitrogen leakage, Soil Biol. Biochem., 59, 38-48, 2013.

Baskaran, P., Hyvönen, R., Berglund, S. L., Clemmensen, K. E., Ågren, G. I., Lindahl, D. B., and Manzoni, S.: Modelling the influence of ectomycorrhizal decomposition on plant nutrition and soil carbon sequestration in boreal forest ecosystems, New Phytol., 213, 1452-1465, 2017.

Berggren Kleja, D., Svensson, M., Majdi, H., Jansson, P. E., Langvall, O., Bergkvist, B., Johansson, M.-B., Weslien, P., Truusb, L., Lindroth, A., and Agren, G.: Pools and fluxes of carbon in three Norway spruce ecosystems along a climatic gradient in Sweden, Biogeochemistry, 89, 7-25, 2008.

Beven, K. J.: A manifesto for the equifinality thesis, J. Hydrology, 320, 18-36, 2006.

Brunner, I., Bakker, M., Björk, R., Hirano, Y., Lukac, M., Aranda, X., Borja, I., Eldhuset, T., Helmisaari, H., Jourdan, C., Konopka, B., Lopez, B., Miguel Perez, C., Persson, H., and Ostonen, I.: Fine-root turnover rates of European forests revisited: an analysis of data from sequential coring and ingrowth cores, Plant Soil, 362, 357-372, https://doi.org/10.1007/s11104-012-1313-5, 2012.

Choma, M., Rappe-George, M. O., Čapek, P., Bárta, J., Kaštovská, E., Gärdenäs, A. I., Šantrůčková H.: Recovery of the ectomycorrhizal community after termination of long-term nitrogen fertilisation of a boreal Norway spruce forest, Fungal Ecology, 29, 116-122, https://doi.org/10.1016/j.funeco.2016.10.002, 2017.

Clemmensen, K. E., Bahr, A., Ovaskainen, O., Dahlberg, A., Ekblad, A., Wallander, H., Stenlid, J., Finlay, R. D., Wardle, D. A., and Lindahl, B. D.: Roots and Associated Fungi Drive Long-Term Carbon Sequestration in Boreal Forest, Science, 339, 1615-1618, 2013.
Coucheney, E., Strömgren, M., Lerch, T. Z., and Herrmann, A. M.: long term fertilization of a boreal Norway spruce forest increases the temperature sensitivity of soil organic carbon mineralization, Ecol. Evol., 3, 5177-5188, 2013.

Deckmyn, G., Verbeeck, H., de Beeck, M. O., Vansteenkiste, D., Steppe, K., and Ceulemans, R.: ANAFORE: A stand-scale process-based forest model that includes wood tissue development and labile carbon storage in trees, Ecol. Model., 215, 345368, 2008.

Deckmyn, G., Meyer, A., Smits, M., Ekblad, A., Grebenc, T., Komarov, A., and Kraigher, H.: Simulating ectomycorrhizal fungi and their role in carbon and nitrogen cycling in forest ecosystems, Can. J. Forest Res., 44, 335-355, 2014.

Dixon, R. K.: Carbon Pools and Flux of Global Forest Ecosystems, Science, 265, 171-171, 1994.

Ekblad, A., Wallander, H., Godbold, D. L., Cruz, C., Johnson, D., Baldrian, P., Björk, R. G., Epron, D., Kieliszewska-Rokicka, B., Kjøller, R., Kraigher, H., Matzner, E., Neumann, J., and Plassard, C.: The production and turnover of extramatrical mycelium of ectomycorrhizal fungi in forest soils: role in carbon cycling, Plant Soil, 366, 1-27, 2013.

Finlay, R.: Ecological aspects of mycorrhizal symbiosis: with special emphasis on the function diversity of interactions involving the extraradical mycelium, J. Exp. Bot., 59, 1115-1126, 2008.

Franklin, O., Näsholm, T., Högberg, P., and Högberg, M. N.: Forests trapped in nitrogen limitation - an ecological market perspective on ectomycorrhizal symbiosis, New Phytol., 203, 657-666, 2014.

Fransson, P. M. and Johansson, E. M.: Elevated $\mathrm{CO}_{2}$ and nitrogen influence exudation of soluble organic compounds by ectomycorrhizal root systems, FEMS Microbiol. Ecol., 71, 186-196, 2010.

Haas, E., Klatt, S., Frohlich, A., Kraft, P., Werner, C., Kiese, R., Grote, R., Breuer, L., and Butterbach-Bahl, K.: LandscapeDNDC: a process model for simulation of biosphere-atmospherehydrosphere exchange processes at site and regional scale, Landscape Ecol., 28, 615-636, 2013.

Harmon, R., and Challenor, P.: A Markov chain Monte Carlo method for estimation and assimilation into models, Ecol. Model., 101, 41-59, https://doi.org/10.1016/S03043800(97)01947-9, 1997.

Hartley, I. P., Garnett, M. H., Sommerkorn, M., Hopkins, D. W., Fletcher, B. J., Sloan, V. L., Phoenix, G. K., and Wookey, P. A.: A potential loss of carbon associated with greater plant growth in the European Arctic, Nat. Clim. Change, 2, 875-879, 2012.

He, H., Kasimir, Å., Jansson, P.-E., Svensson, M., Meyer, A., and Klemedtsson, L.: Factors controlling Nitrous Oxide emission from a spruce forest ecosystem on drained organic soil, derived using the CoupModel, Ecol. Model., 321, 46-63, https://doi.org/10.1016/j.ecolmodel.2015.10.030, 2016.

Högberg, M. and Högberg, P.: Extramatrical ectomycorrhizal mycelium contributes one-third of microbial biomass and produces, together with associated roots, half the dissolved organic carbon in a forest soil, New Phytol., 154, 791-795, 2002.

Högberg, M., Briones, M., Keel, S., Metcalfe, D., Campbell, C., Midwood, A., Thornton, B., Hurry, V., Linder, S., Näsholm, T., and Högberg, P.: Quantification of effects of season and nitrogen supply on tree below-ground carbon transfer to ectomycorrhizal 
fungi and other soil organisms in a boreal pine forest, New Phytol., 187, 485-493, 2010.

Högberg, P., Näsholm, T., Franklin, O., and Högberg, M. N.: Tamm Review: On the nature of the nitrogen limitation to plant growth in Fennoscandian boreal forests, Forest Ecol. Manage., 403, 161$185,2017$.

Huang, S., Arain, M. A., Arora, V. K., Yuan, F., Brodeur, J., and Peichl, M.: Analysis of nitrogen controls on carbon and water exchanges in a conifer forest using the CLASS-CTEMN+ model, Ecol. Model., 222, 3743-3760, 2011.

Hyvönen, R., Persson, T., Andersson, S., Olsson, B., Ågren, G. I., and Linder, S.: Impact of long-term nitrogen addition on carbon stores in trees and soils in northern Europe, Biogeochemistry, 89, 121-137, 2008.

Jansson, P.-E.: CoupModel: model use, calibration, and validation, T. ASABE, 55, 1335-1344, 2012.

Jansson, P.-E. and Karlberg, L.: Coupled Heat and Mass Transfer Model for Soil-Plant-Atmosphere Systems, Royal Institute of Technology, Stockholm, 484 pp., available at: http://www. coupmodel.com/default.htm, 2011.

Jansson, P.-E. and Moon, D. S.: A coupled model of water, heat and mass transfer using object orientation to improve flexibility and functionality, Environ. Model. Softw., 16, 37-46, 2001.

Johnson, D., Ijdo, M., Genney, D., Anderson, I., and Alexander, I.: How do plants regulate the function, community structure, and diversity of mycorrhizal fungi?, J. Exp. Bot., 417, 1751-1760, 2005.

Kirschbaum, M. U. and Paul, K. I.: Modelling C and N dynamics in forest soils with a modified version of the CENTURY model, Soil Biol. Biochem., 34, 341-354, 2002.

Kjoller, R., Nilsson, L. O., Hansen, K., Schmidt, I. K., Vesterdal, L., and Gundersen, P.: Dramatic changes in ectomycorrhizal community composition, root tip abundance and mycelial production along a stand-scale nitrogen deposition gradient, New Phytol., 194, 278-286, 2012.

Klemedtsson, L., von Arnold, K., Weslien, P., and Gundersen, P.: Soil CN ratio as a scalar parameter to predict nitrous oxide emissions, Glob. Change Biol., 11, 1142-1147, 2005.

Klemedtsson, L., Jansson, P., Gustafsson, D., Karlberg, L., Weslien, P., von Arnold, K., Ernfors, M., Langvall, O., and Lindroth, A.: Bayesian calibration method used to elucidate carbon turnover in forest on drained organic soil, Biogeochemistry, 89, 61-79, 2008

Leake, J.: Mycorrhizas and the terrestrial carbon cycle: roles in global carbon sequestration and plant community composition, in: Fungi in the environment, edited by: Gadd, G. M., Watkinson, S. C., and Dyer, P. S., Cambridge University Press, Cambridge, 161-185, 2007.

Leuschner, C., Hertel, D., Schmid, I., Koch, O., Muhs, A., and Holscher, D.: Stand fine root biomass and fine root morphology in old-growth beech forests as a function of precipitation and soil fertility, Plant Soil, 258, 43-56, 2004.

Lim, H., Oren, R., Palmroth, S., Tor-ngern, P., Mörling, T., Näsholm, T., Lundmark, T., Helmisaari, H.-S., LeppälammiKujansuu, J., and Linder, S.: Inter-annual variability of precipitation constrains the production response of boreal to nitrogen fertilization, Forest Ecol. Manage., 348, 31-45, https://doi.org/10.1016/j.foreco.2015.03.029, 2015.
Lindahl, B. D. and Tunlid, A.: Ectomycorrhizal fungi-potential organic matter decomposers, yet not saprotrophs, New Phytol., 205, 1443-1447, 2015.

Lindroth, A., Klemedtsson, L., Grelle, A., Weslien, P., and Langvall, O.: Measurement of net ecosystem exchange, productivity and respiration in three spruce forests in Sweden shows unexpectedly large soil carbon losses, Biogeochemistry, 89, 43-60, 2008.

Luo, G. J., Brüggemann, N., Wolf, B., Gasche, R., Grote, R., and Butterbach-Bahl, K.: Decadal variability of soil $\mathrm{CO}_{2}, \mathrm{NO}$, $\mathrm{N}_{2} \mathrm{O}$, and $\mathrm{CH}_{4}$ fluxes at the Höglwald Forest, Germany, Biogeosciences, 9, 1741-1763, https://doi.org/10.5194/bg-9-17412012, 2012.

Magnani, F., Mencuccini, M., Borghetti, M., Berbigier, P., Berninger, F., Delzon, S., Grelle, A., Hari, P., Jarvis, P. G., Kolari, P., Kowalski, A. S., Lankreijer, H., Law, B. E., Lindroth, A., Loustau, D., Manca, G., Moncrieff, J. B., Rayment, M., Tedeschi, V., Valentini, R., and Grace, J.: The human footprint in the carbon cycle of temperate and boreal forests, Nature, 447, 848-850, 2007.

Mäkiranta, P., Hytonen, J., Aro, L., Maljanen, M., Pihlatie, M., Potila, H., Shurpali, N., Laine, J., Lohila, A., Martikainen, P., and Minkkinen, K.: Soil greenhouse gas emissions from afforested organic soil croplands and cutaway peatlands, Boreal Environ. Res., 12, 159-175, 2007.

Maljanen, M., Sigurdsson, B. D., Gudmundsson, J., Óskarsson, H., Huttunen, J. T., and Martikainen, P. J.: Greenhouse gas balances of managed peatlands in the Nordic countries present knowledge and gaps, Biogeosciences, 7, 2711-2738, https://doi.org/10.5194/bg-7-2711-2010, 2010.

Martikainen, P., Nykanen, H., Alm, J., and Silvola, J.: Change in Fluxes of Carbon-Dioxide, Methane and Nitrous-Oxide Due to Forest Drainage of Mire Sites of Different Trophy, Plant Soil, 168, 571-577, 1995.

Meyer, A., Grote, R., Polle, A., and Butterbach-Bahl, K.: Simulating mycorrhiza contribution to forest $\mathrm{C}$ - and $\mathrm{N}$ cycling-the MYCOFON model, Plant Soil, 327, 493-517, 2010.

Meyer, A., Grote, R., and Butterbach-Bahl, K.: Integrating mycorrhiza in a complex model system: effects on ecosystem $\mathrm{C}$ and $\mathrm{N}$ fluxes, Eur. J. For. Res., 131, 1809-1831, 2012.

Moore, J. A. M., Jiang, J., Post, W. M., and Classen, A. T.: Decomposition by ectomycorrhizal fungi alters soil carbon storage in a simulated model, Ecosphere, 6, 1-16, https://doi.org/10.1890/ES14-00301.1, 2015.

Näsholm, T., Högberg, P., Franklin, O., Metcalfe, D., Keel, S. G., Campbell, C., Hurry, V., Linder, S., and Högberg, M. N.: Are ectomycorrhizal fungi alleviating or aggravating nitrogen limitation of tree growth in boreal forests?, New Phytol., 198, 214-221, 2013.

Nehls, U.: Mastering ectomycorrhizal symbiosis: the impact of carbohydrates, J. Exp. Bot., 59, 1097-1108, 2008.

Olsson, M. T., Erlandsson, M., Lundin, L., Nilsson, T., Nilsson, Å., and Stendahl, J.: Organic carbon stocks in Swedish Podzol soils in relation to soil hydrology and other site characteristics, Silva Fennica, 43, 209-222, 2007.

Orwin, K., Kirschbaum, M., St John, M., and Dickie, I.: Organic nutrient uptake by mycorrhizal fungi enhances ecosystem carbon storage: a model-based assessment, Ecol. Lett., 14, 493-502, https://doi.org/10.1111/j.1461-0248.2011.01611.x, 2011. 
Pan, Y., Birdsey, R. A., Fang, J., Houghton, R., Kauppi, P. E., Kurz, W. A., Phillips, O. L., Shvidenko, A., Lewis, S. L., Canadell, J. G., Ciais, P., Jackson, R. B., Pacala, S. W., McGuire, A. D., Piao, S. L., Rautiainen, A., Sitch, S., and Hayes, D.: A large and persistent carbon sink in the world's forests, Science, 333, 988993, 2011

Parker, T. C., Subke, J. A., and Woody, P. A.: Rapid carbon turnover beneath shrub and tree vegetation is associated with low soil carbon stocks at a subarctic treeline, Glob. Change Biol., 21, 20702081, 2015.

Plassard, C., Schroemm, P., Mouisan, D., and Salsac, L.: Assimilation of mineral nitrogen and ion balance $i$ the two partners of ectomycorrhizal symbiosis: Data and hypothesis, Cell Mol. Life Sci., 47, 340-349, 1991.

Pritsch, K., Raidl, S., Marksteiner, E., Blaschke, H., Agerer, R., Schloter, M., and Hartmann, A.: A rapid and highly sensitive method for measuring enzyme activities in single mycorrhizal tips using 4-methylumbelliforme-labelled fluorogenic substrates in a microplate system, J. Microbiol. Methods, 58, 233-241, 2004.

Read, D.: Mycorrhizas in Ecosystems, Experientia, 47, 376-391, 1991.

Read, D. and Perez-Moreno, J.: Mycorrhizas and nutrient cycling in ecosystems - a journey towards relevance?, New Phytol., 157, 475-492, 2003.

Ricciuto, D. M., Davis, K. J., and Keller, K.: A Bayesian calibration of a simple carbon cycle model: The role of observations in estimating and reducing uncertainty, Global Biogeochem. Cy., 22, GB2030, https://doi.org/10.1029/2006GB002908, 2008.

Rubinstein, R. Y. and Kroese, D. P.: Simulation and the Monte Carlo Method, 3rd edn., Wiley, Hoboken, 432 pp., 2016.

Schulze, E. D., Luyssaert, S., Ciais, P., Freibauer, A., Janssens, I. A., Soussana, J. F., Smith, P., Grace, J., Levin, I., Thiruchittampalam, B., Heimann, M., Dolman, A. J., Valentini, R., Bousquet, P., Peylin, P., Peters, W., Rodenbeck, C., Etiope, G., Vuichard, N., Wattenbach, M., Nabuurs, G. J., Poussi, Z., Nieschulze, J., and Gash, J. H.: Importance of methane and nitrous oxide for Europe's terrestrial greenhouse-gas balance, Nat. Geosci., 2, 842 850,2009

Sierra, C. A., Malghani, S., and Müller, M.: Model structure and parameter identification of soil organic matter models, Soil Biol. Biochem., 90, 197-203, 2015.

Sitch, S., Smith, B., Prentice, I. C., Arneth, A., Bondeau, A., Cramer, W., Kaplan, J. O., Levis, S., Lucht, W., Sykes, M. T., Thonicke, K., and Venevsky, S.: Evaluation of ecosystem dynamics, plant geography and terrestrial carbon cycling in the LPJ dynamic global vegetation model, Glob. Change Biol., 9, 161-185, 2003.

Smith, B., Samuelsson, P., Wramneby, A., and Rummukainen, M.: A model of the coupled dynamics of climate, vegetation and terrestrial ecosystem biogeochemistry for regional applications, Tellus A, 63, 87-106, 2011.

Smith, S. and Read, D.: Mycorrhizal Symbiosis, Academic Press, 3rd edn., London, 800 pp., 2008.

Staddon, P., Ramsey, C., Ostle, N., Ineson, P., and Fitter, A.: Rapid turnover of hyphae of mycorrhizal fungi determined by AMS microanalysis of C-14, Science, 300, 1138-1140, 2003.

Svensson, M., Jansson, P. E., and Kleja, D. B.: Modelling soil C sequestration in spruce forest ecosystems along a Swedish tran- sect based on current conditions, Biogeochemistry, 89, 95-119, 2008a.

Svensson, M., Jansson, P. E., Gustafsson, D., Kleja, D. B., Langvall, O., and Lindroth, A.: Bayesian calibration of a model describing carbon, water and heat fluxes for a Swedish boreal forest stand, Ecol. Model., 213, 331-344, 2008b.

Taylor, A. and Alexander, I.: The ectomycorrhizal symbiosis: life in the real world, Mycoologist, 19, 102-112, 2005.

Thornley, J. and Cannell, M.: Modelling the components of plant respiration: representation and realism, Ann. Botany, 85, 55-67, 2000.

van der Heijden, M. G. A., Bardgett, R. D., and van Straalen, N. M.: The unseen majority: soil microbes as drivers of plant diversity and productivity in terrestrial ecosystems, Ecol. Lett., 11, 296310,2008 .

van Oijen, M., Rougier, J., and Smith, R.: Bayesian calibration of process-based forest models: bridging the gap between models and data, Tree Physiol., 25, 915-927, 2005.

Vitousek, P. M. and Howarth, R. W.: Nitrogen limitation on land and in the sea: How can it occur?, Biogeochemistry, 13, 87-115, 1991.

von Arnold, K., Weslien, P., Nilsson, M., Svensson, B., and Klemedtsson, L.: Fluxes of $\mathrm{CO}_{2}, \mathrm{CH}_{4}$ and $\mathrm{N}_{2} \mathrm{O}$ from drained coniferous forests on organic soils, For. Ecol. Manage., 210, 239-254, 2005.

Vrugt, J. A.: Markov chain Monte Carlo simulation using the DREAM software package: Theory, concepts, and MATLAB implementation, Environ. Model. Softw., 75, 273-316, 2016.

Wallander, H. and Nilsson, L.: Direct estimates of $\mathrm{C}: \mathrm{N}$ ratios of ectomycorrhizal mycelia collectes from Norway spruce forest soils, Soil Biol. Biochem., 35, 997-999, 2003.

Wallander, H., Göransson, H., and Rosengreen, U.: Production, standing biomass and natural abundance of $15 \mathrm{~N}$ and $13 \mathrm{C}$ in ectomycorrhizal mycelia collected at different soil depth in two forest types, Oecologia, 139, 89-97, 2004.

Wallander, H., Fossum, A., Rosengren, U., and Jones, H.: Ectomycorrhizal fungal biomass in roots and uptake of $\mathrm{P}$ from apatite by Pinus sylvestris seedlings growing in forest soil with and without wood ash amendment, Mycorrhiza, 15, 143-148, 2005.

Wallander, H., Ekblad, A., and Bergh, J.: Growth and carbon sequestration by ectomycorrhizal fungi in intensively fertilized Norway spruce forests, Forest Ecol. Manage., 262, 999-1007, 2011.

Wallander, H., Ekblad, A., Godbold, D. L., Johnson, D., Bahr, A., Baldrian, P., Bjork, R. G., Kieliszewska-Rokicka, B., Kjoller, R., Kraigher, H., Plassard, C., and Rudawska, M.: Evaluation of methods to estimate production, biomass and turnover of ectomycorrhizal mycelium in forests soils - A review, Soil Biol Biochem., 57, 1034-1047, 2013.

Wallenda, T. and Kottke, I.: Nitrogen deposition and ectomycorrhizas, New Phytol., 139, 169-187, 1998.

Wang, Y. P., Leuning, R., Cleugh, H. A., and Coppin, P. A.: parameter estimation in surface exchange models using nonlinear inversion: how many parameters can we estimate and which measurements are most useful?, Glob. Change Biol., 7, 495-510, 2001.

Wu, S. H., Jansson, P.-E., and Kolari, P.: The role of air and soil temperature in the seasonality of photosynthesis and transpiration in a boreal Scots pine ecosystem, Agricult. Forest Meteorol., 156, 85-103, 10.1016/j.agrformet.2012.01.006, 2012. 
Yeluripati, J. B., van Oijen, M., Wattenbach, M., Neftel, A., Ammann, A., Parton, W. J., and Smith, P.: Bayesian calibration as a tool for initialising the carbon pools of dynamic soil models, Soil Biol. Biochem., 41, 2579-2583, 2009. 